\title{
Impaired Leptomeningeal Collateral Flow Contributes to the Poor Outcome following Experimental Stroke in the Type 2 Diabetic Mice
}

\author{
Yosuke Akamatsu, ${ }^{1,2,3}$ Yasuo Nishijima, ${ }^{1,2,3}$ Chih Cheng Lee, ${ }^{1,2}$ Shih Yen Yang, ${ }^{1,2}$ Lei Shi, ${ }^{4}$ Lin An, ${ }^{4}$ Ruikang K. Wang, ${ }^{4}$ \\ Teiji Tominaga, ${ }^{3}$ and Jialing Liu ${ }^{1,2}$ \\ ${ }^{1}$ Department of Neurological Surgery, University of California at San Francisco and ${ }^{2}$ San Francisco Veterans Affairs Medical Center, San Francisco, \\ California 94121, ${ }^{3}$ Department of Neurosurgery, Tohoku University Graduate School of Medicine, Sendai 980-8574, Japan, and ${ }^{4}$ Departments of \\ Bioengineering and Ophthalmology, University of Washington, Seattle, Washington 98195
}

Collateral status is an independent predictor of stroke outcome. However, the spatiotemporal manner in which collateral flow maintains cerebral perfusion during cerebral ischemia is poorly understood. Diabetes exacerbates ischemic brain damage, although the impact of diabetes on collateral dynamics remains to be established. Using Doppler optical coherent tomography, a robust recruitment of leptomeningeal collateral flow was detected immediately after middle cerebral artery (MCA) occlusion in C57BL/6 mice, and it continued to grow over the course of 1 week. In contrast, an impairment of collateral recruitment was evident in the Type 2 diabetic $d b / d b$ mice, which coincided with a worse stroke outcome compared with their normoglycemic counterpart $d b /+$, despite their equally well-collateralized leptomeningeal anastomoses. Similar to the wild-type mice, both $d b /+$ and $d b / d b$ mice underwent collateral growth $7 \mathrm{~d}$ after MCA stroke, although $d b / d b$ mice still exhibited significantly reduced retrograde flow into the MCA territory chronically. Acutely induced hyperglycemia in the $d b /+$ mice did not impair collateral flow after stroke, suggesting that the state of hyperglycemia alone was not sufficient to impact collateral flow. Human albumin was efficacious in improving collateral flow and outcome after stroke in the $d b / d b$ mice, enabling perfusion to proximal MCA territory that was usually not reached by retrograde flow from anterior cerebral artery without treatment. Our results suggest that the impaired collateral status contributes to the exacerbated ischemic injury in mice with Type 2 diabetes, and modulation of collateral flow has beneficial effects on stroke outcome among these subjects.

Key words: anastomosis; arteriogenesis; Doppler OCT; MCA0; metabolic syndrome; vascular remodeling

\section{Introduction}

Type 2 diabetes mellitus (T2DM) is a major risk factor of ischemic stroke (Emerging Risk Factors Collaboration et al., 2010) and associated with an increased risk of long-term functional deficits after stroke (Megherbi et al., 2003). However, the mechanisms that are responsible for the worse stroke outcome in this population are incompletely understood. Hyperglycemia exists in $30 \%-40 \%$ of patients with acute ischemic stroke and is independently associated with a poor outcome (Parsons et al., 2002;

\footnotetext{
Received Sept. 11, 2014; revised 0ct. 6, 2014; accepted Jan. 21, 2015

Author contributions: J.L. designed research; Y.A., Y.N., C.C.L., S.Y.Y., L.S., and J.L. performed research; L.A., R.K.W., T.T., and J.L. contributed unpublished reagents/analytic tools; Y.A., Y.N., C.C.L., S.Y.Y., L.A., and J.L. analyzed data; Y.A. and J.L. wrote the paper.

This work was supported by National Institutes of Health Grant R01 NS071050 to J.L., Veterans Administration Merit Award I01RX000655 to J.L., American Heart Hospital Association EIA 0940065N to J.L., and NIH R01HL093140 to R.K.W. We thank Dr. Philip Weinstein (University of California at San Francisco) for helpful discussion and Ilona Garner (University of California at San Francisco) for editorial assistance.

The authors declare no competing financial interests.

Correspondence should be addressed to Dr. Jialing Liu, Department of Neurological Surgery (112C), University of California at San Francisco and Department of Veterans Affairs Medical Center, 1700 Owens Street, San Francisco, CA 94158. E-mail: jialing.liu@ucsf.edu.

DOI:10.1523/JNEUROSCI.3838-14.2015

Copyright $\odot 2015$ the authors $\quad 0270-6474 / 15 / 353851-15 \$ 15.00 / 0$
}

Martini and Kent, 2007; Fuentes et al., 2009), even among those who have not been diagnosed with diabetes. Hyperglycemia increases oxidative stress during cerebral ischemia (Won et al., 2011), yet it is unclear whether acute hyperglycemia per se or other underlying vascular pathology contributes to this increased morbidity.

A confluence of clinical evidences suggests that the collateral status is an independent predictor of outcome and response to thrombolytic therapies in patients with ischemic stroke, and a good collateral status can lower the rate of hemorrhagic transformation after thrombolytic and endovascular therapies (Liebeskind, 2003, 2013; Shuaib et al., 2011; Liu et al., 2014). Furthermore, patients with metabolic syndromes are associated with poor anatomical collateral status during acute ischemic stroke (Menon et al., 2013). It remains to be established whether impaired cerebral collateral flow regulation occurs during stroke in subjects with T2DM and whether the impairment is related to hyperglycemia.

Human albumin, a potent neuroprotective agent proven in preclinical and clinical stroke studies (Belayev et al., 2002; Hill et al., 2011), of which the treatment effects can be partially attributed to its hemodynamic and intravascular effects that improve 
blood flow (Nimmagadda et al., 2008). However, it remains unclear whether albumin enhances leptomeningeal collateral flow in middle cerebral artery (MCA) stroke and whether it can also be effective in diabetic subjects who often do not respond to vascular interventions.

Doppler optical coherence tomography (DOCT) has emerged as a new technique to assess dynamic cerebral blood flow with excellent spatial resolution and sensitivity in quantifying velocity (Wang and An, 2009). The main advantages of DOCT over other available optical imaging methods include the capability of quantifying blood flow across many individual vessels simultaneously at a relatively high speed in the presence of an intact cranium (Wang and An, 2009; Srinivasan et al., 2011), as well as providing absolute blood perfusion values in repeated measurement (Santisakultarm and Schaffer, 2011). In the current study, we examined the spatial and temporal changes of the leptomeningeal collateral flow following MCA stroke in normal and diabetic mice for the first time using DOCT. Our results indicate that the impaired collateral flow dynamics in T2DM mice after MCA stroke is not attributed to acute hyperglycemia, and it can be improved by human albumin that enhances retrograde collateral flow deep into the proximal MCA territory.

\section{Materials and Methods}

Animals and housing. This study was conducted in accordance with the animal care guidelines issued by the National Institutes of Health and by the San Francisco Veterans Administration Medical Center Animal Use and Care Committee. Male C57BL/6J, $d b / d b$, and $d b /+$ mice (16-20 weeks old, The Jackson Laboratory) were housed 4 per cage on a $12 \mathrm{~h}$ dark/light cycle with access to food and water ad libitum.

Middle cerebral artery occlusion (MCAO). Stroke was induced unilaterally in mice for $90 \mathrm{~min}$ using the distal MCAO method with modifications (Sun et al., 2013). Because a permanent distal ligation of the MCA does not give reproducible infarct in most mouse strains, we combined it with a unilateral common carotid artery (CCA) occlusion. Anesthesia was induced with $3 \%$ isoflurane in a closed chamber and maintained with $2 \%$ isoflurane in $30 \% \mathrm{O}_{2}$ and $70 \% \mathrm{~N}_{2} \mathrm{O}$ with a facemask. Core temperature was maintained at $37 \pm 0.5^{\circ} \mathrm{C}$ with a heating blanket and rectal thermistor servo-loop. Systemic blood pressure was monitored using the volume-pressure recording technology to detect changes in tail volume that correspond to systolic and diastolic blood pressure (CODA noninvasive blood pressure system, Kent Scientific). With the mouse in a prone position fixed in a head holder (Stoelting), the scalp was cut meticulously with a surgical knife to expose the thin skull (calvaria) over the bilateral cerebral and cerebellar hemispheres without causing brain trauma. The left CCA was isolated from the adjacent vagus nerve, dissected out of the carotid sheath, and a 7-0 nylon suture noose was placed across the CCA from the bottom, ready for temporary ligation. The mouse was then placed in a lateral position. A straight skin incision was made along the sagittal suture, and scalp was retracted to inferior. A 1.5 -mm-diameter burr hole $1.2 \mathrm{~mm}$ rostral to the anterior junction of the zygoma and temporalis bone was made with a dental drill. Immediately after the opening of the dura with a fine needle, the MCA was permanently occluded and cut at the distal to lenticulostriate artery with a microbipolar electrocoagulator at minimal power, followed by an immediate temporary ligation of the ipsilateral CCA for 90 min. Shamoperated mice did not receive occlusion of either the MCA or CCA.
DOCT. To evaluate changes in blood vessel diameter and flow velocity during ischemic stroke and reperfusion, we used DOCT (Wang and An, 2009), a noninvasive high-resolution 3D optical imaging technique for microangiography. The system configuration of DOCT of our custom design is shown in Figure 1. The superluminescent diode illuminated broadband infrared light with the center wavelength of $1310 \mathrm{~nm}$ at the mouse brain via the sample arm. The backscattered signal interfered with the counterpart from the reference arm was entered into a high-speed spectrometer and recorded by a line-scan infrared camera. The 2D transverse scanning as well as Fourier transformation of the spectral data yielded $3 \mathrm{D}$ imaging data that were composed of $512 \times 5000 \times 300$ (depth $\times$ fast axis $\times$ slow axis) voxel cube, covering $2.3 \times 2.2 \times 2.2 \mathrm{~mm}^{3}$ of brain tissue. Flow data were collected from a total of 6 voxel cubes $(3 \times$ 2 in horizontal and vertical dimension) per animal with a motorized stage (ThorLabs). Doppler velocity signals were extracted from the imaging data by processing their phase differences between adjacent fastaxis scans. The backscattered red light and the brain microscopy were recorded together in an area-scan visible-light camera to monitor the scanning position on the brain. The full-width half-maximum of the system point spread function was measured at $7 \mu \mathrm{m}(z$, or axial resolution) and $8 \mu \mathrm{m}(x-y$, or lateral resolution), respectively. Thus, the system resolution is approximately in the size of average capillary vessels in the brain. In addition to system resolution, the sensitivity of DOCT is also related to the minimal velocity of a vessel.

DOCT imaging was conducted under isoflurane anesthesia through an intact skull at baseline, during MCAO, at various time points after occlusion or reperfusion, and following hyperglycemia induction or drug treatment as indicated in each experiment. Each imaging session lasted $\sim 30-40 \mathrm{~min}$. During acquisition, the axis speed was set at $57 \mathrm{kHz}$ or $19 \mathrm{kHz}$ with axial velocity in the range of -13.8 to 13.8 or -4.6 to 4.6 $\mathrm{mm} / \mathrm{s}$ for baseline or postocclusion imaging, respectively. All the data processing was performed in customized MATLAB (MathWorks) programs and was visualized in the 3D software AMIRA (Visual Imaging). The vessel diameter was measured in en-face projection images of the Doppler data. The absolute blood flow was calculated by integrating the axial velocity signals. Five boxes along the region of interest were selected and averaged to obtain the data. As red blood cell velocity and lumen diameter can change independently of each other, we also determined the volume flux in each vessel (Schaffer et al., 2006) as flux $=v \pi R^{2}$, where $v$ is the average flow velocity over the cross-sectional area of the vessel lumen and $R$ is the lumen radius. 

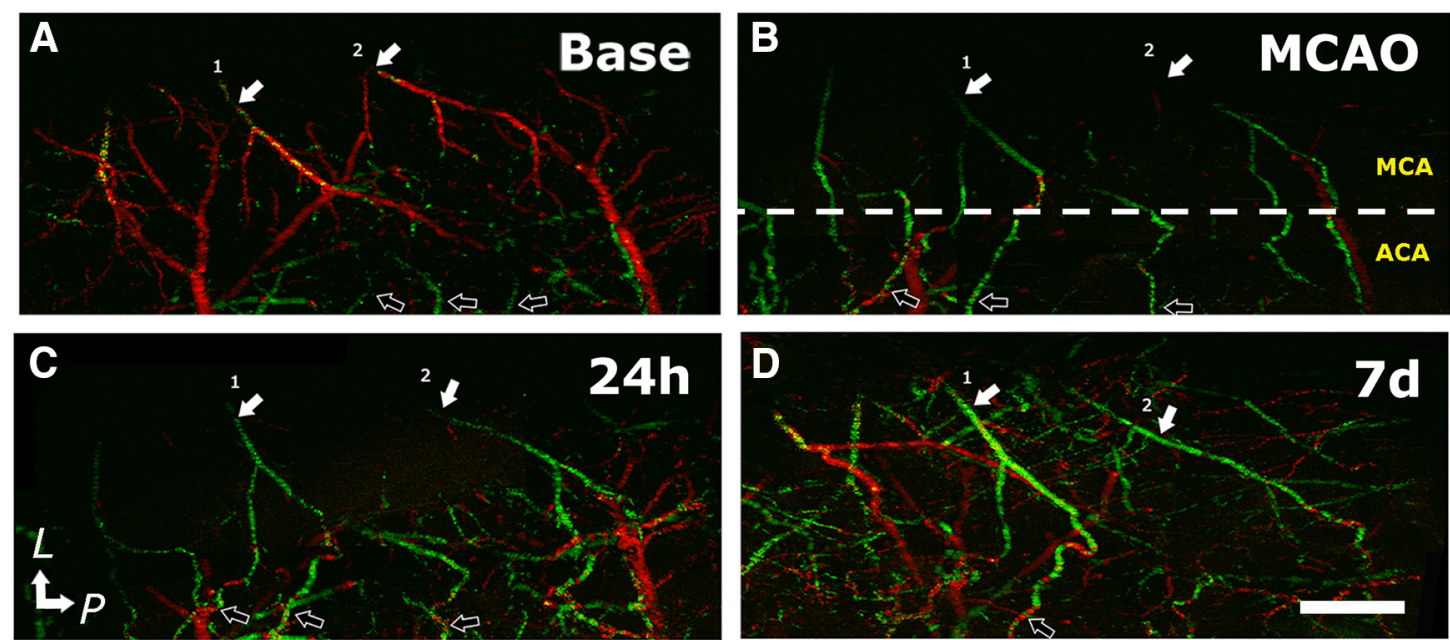

$\mathbf{E}$

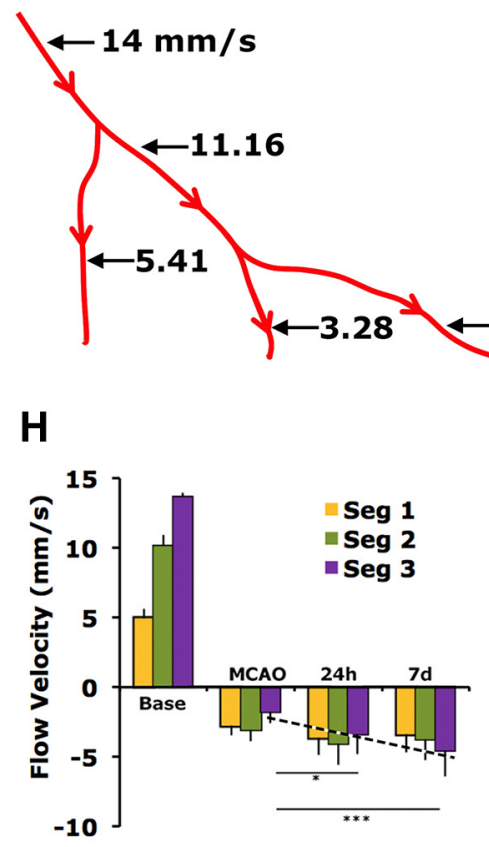

$\mathbf{F}$
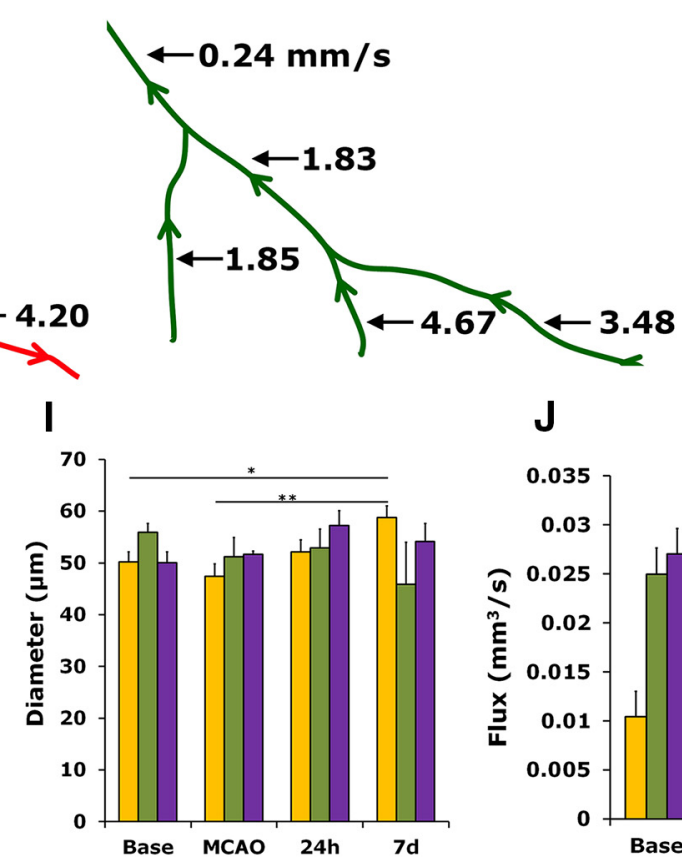

G

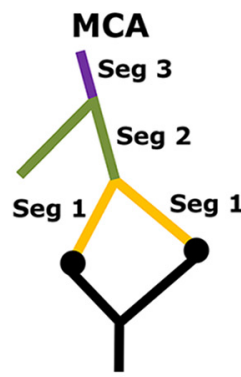

Figure 2. Spatiotemporal flow dynamics in flow velocity, flux, and arterial diameter following MCAO in C57BL/6 mice. Representative DOCT images before $(\boldsymbol{A})$, during $(\boldsymbol{B})$, and after MCAO (C,D) from the same mouse. White- and black-filled arrows indicate MCA and ACA branches, respectively. The direction of blood flow is color-coded, with the blood flowing toward the scanning probe beam coded designated as red, and the opposite direction as green. Dotted white line indicates the divide between MCA and ACA territory shown in $\boldsymbol{B}$. The anatomic orientation of the brain is indicated with arrows pointing to the lateral $(\mathrm{L})$ and posterior $(\mathrm{P})$ directions in $\boldsymbol{C}$. Arterial tree 1 at baseline $(\boldsymbol{E})$ and during $M C A 0(\boldsymbol{F})$ showing the direction of flow and flow velocity at various points. At baseline, MCA velocity decreased progressively in the downstream branches. During MCA0, the velocity of retrograde flow also decreased progressively toward proximal MCA. G, Classification of MCA branches according to the proximity to MCA-ACA anastomoses (black dots) with the most distal MCA braches assigned as segment 1 (Seg 1) and the most proximal ones as segment 3 (Seg 3). In general, flow velocity and flux decreased after MCAO in all segments, whereas the diameters of vessels investigated displayed relatively small changes. Specifically, flow velocity $(\boldsymbol{H})$ of Seg 3 has progressively increased over time after MCA0. The diameter of Seg 1 was enlarged at $7 \mathrm{~d}$ after MCAO relative to that at baseline and during MCA0, indicating the growth of collateral vessels after stroke (I). Flux also showed a significant increase at $7 \mathrm{~d}$ after MCAO in Seg $3(J)$. Scale bar, $1 \mathrm{~mm} .{ }^{*} p<0.05 .{ }^{* *} p<0.01 .{ }^{* * *} p<0.005 .{ }^{* * * *} p<0.001 . N=5-12$.

Table 1. $d b / d b$ mice are significantly obese and hyperglycemic compared with $d b /+$ mice at $\sim 16-20$ weeks of age, as evidenced by their greater body weight and high fasting blood glucose level ( $N=7-9 /$ group)

\begin{tabular}{lcc}
\hline & $d b /+$ & $d b / d b$ \\
\hline Body weight $(\mathrm{g})$ & $25.8 \pm 0.5$ & $40.3 \pm 0.9^{*}$ \\
Blood glucose (mg/dl) & $156.4 \pm 12.9$ & $382.6 \pm 54.0^{* *}$ \\
\hline$*_{p}<001 . * *_{p}<0.001$ &
\end{tabular}

To assess the change in flow velocity, diameter, and flux after saline or albumin treatment, we subtracted the pretreatment value from the posttreatment value in each parameter within the same subject and averaged the relative change within one treatment group, an approach used in a previous study in assessing cerebral blood flow (Belayev et al., 2002).

Induced hyperglycemia. $d b /+$ mice were rendered hyperglycemic by intraperitoneal injections of $5.0 \mathrm{ml} / \mathrm{kg}$ of $25 \%$ dextrose at $15 \mathrm{~min}$ before baseline DOCT imaging, corresponding to $60 \mathrm{~min}$ before the onset of MCAO. A booster dose of dextrose $(1.5 \mathrm{ml} / \mathrm{kg})$ was injected at $90 \mathrm{~min}$ after the first injection. The vehicle control mice received equal volume of saline during the same time points. Blood glucose was quantified from 

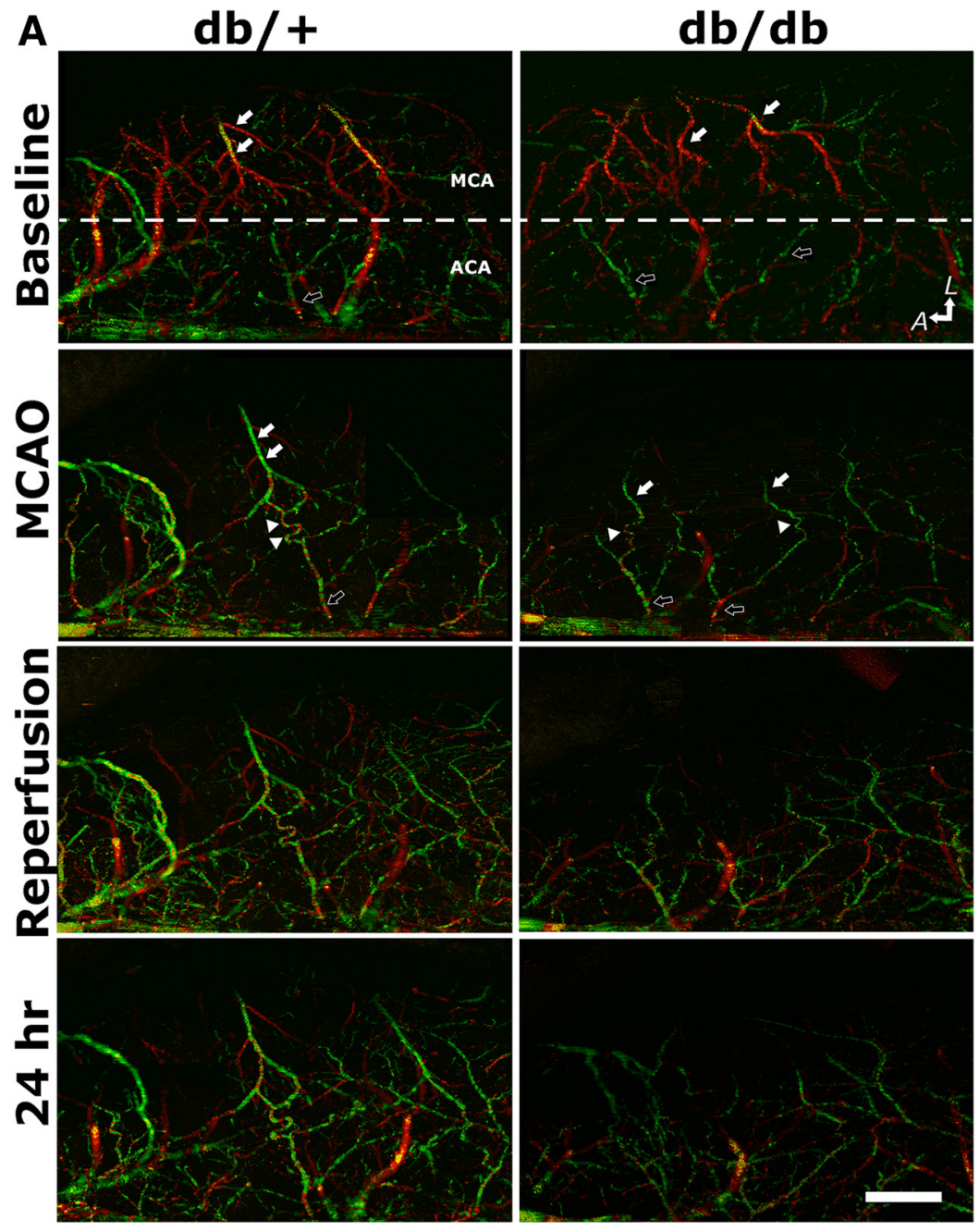

B
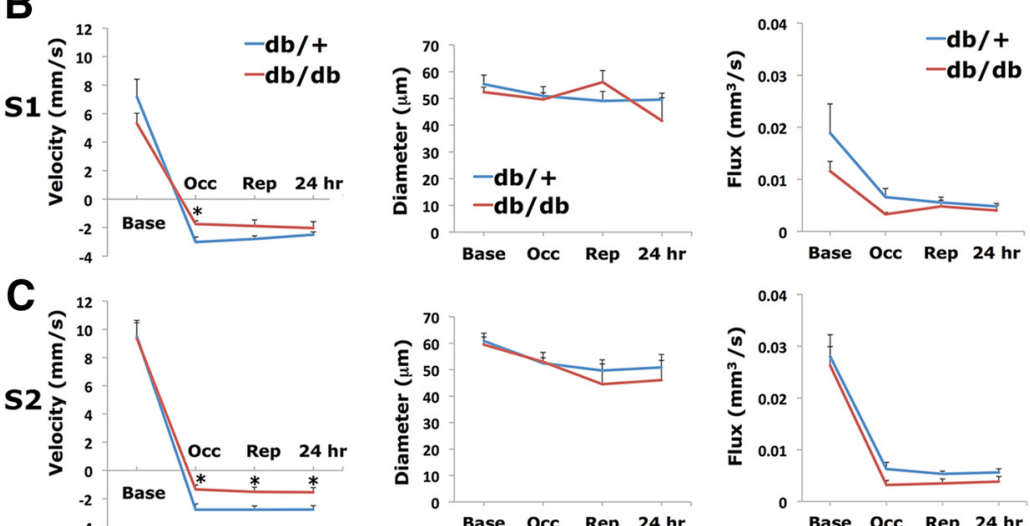

D
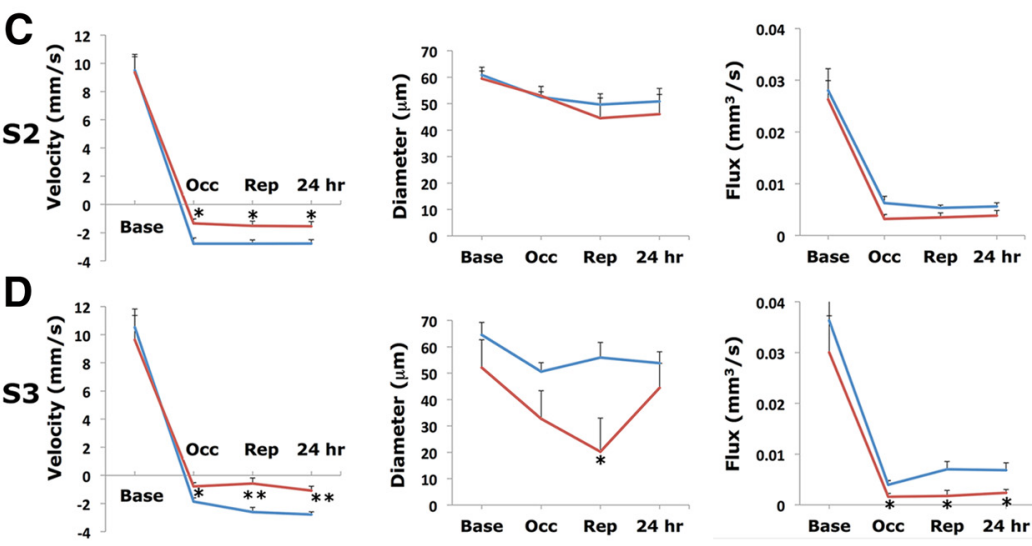

Figure 3. Impairment of collateral flow recruitment after MCAO in the diabetic $d b / d b$ mice. $A$, Representative DOCT images of $d b /+$ and $d b / d b$ mice at baseline, during MCA0, during reperfusion, and at $24 \mathrm{~h}$ after reperfusion. The direction of blood flow is color-coded, with the blood flowing toward the scanning probe beam or toward ACA territory coded as red, and the retrograde flow toward proximal MCA as green. White- and black-filled arrows indicate MCA and ACA branches, respectively. Dotted white lines indicate the divide between MCA and ACA territory The anatomic orientation of the brain is indicated with arrows pointing to the lateral $(\mathrm{L})$ and anterior $(\mathrm{A})$ directions. Arrowheads indicate the tortuous anastomoses between MCA and ACA. Line graphs of time tail vein blood by a glucose monitor (NIPRO) at various time points as indicated.

Albumin treatment. Following the completion of the first DOCT imaging at $60 \mathrm{~min}$ after reperfusion, mice were injected with either $1.25 \mathrm{~g} / \mathrm{kg}$ 25\% human albumin (Baxter) (Belayev et al., 2001) or an equivalent volume of isotonic $(0.9 \%)$ saline solution via the jugular vein over a period of $3 \mathrm{~min}$.

Arterial labeling and scoring. Cerebral arteries were labeled in vivo as described previously with modifications ( $\mathrm{Li}$ et al., 2008). In brief, mice were perfused with $4 \%$ PFA at a rate of 2 $\mathrm{ml} / \mathrm{min}$ for $3 \mathrm{~min}$ followed with $0.2 \%$ lipophilic carbocyanine fluorescent dye, DiI (Invitrogen) at $5 \mathrm{ml} / \mathrm{min}$ for $5 \mathrm{~min}$. A montage image was created by stitching individual images taken at 100× (Axioskop 2, Carl Zeiss) using the Virtue Tissue 3D module (StereoInvestigator, MBF Bioscience). The patency of the posterior communicating arteries (PcomA), the distance between midline and the line of anterial cerebral artery (ACA) and MCA anastomoses, and the number of connecting collaterals between ACA and MCA were assessed. Collaterals refer to arterial anastomoses in our paper, and additional etymology of collateral circulation is as described previously (Faber et al., 2014). The development of left and right PcomA was evaluated using following criteria: 0 , no anastomosis; 1 , anastomosis in the capillary phase; 2, small truncal PcomA; and 3, truncal PcomA.

Assessment of neurobehavioral outcomes. A separate group of mice were used for neurobehavioral outcome and infarct size assessment from those underwent DOCT imaging, to minimize confound due to isoflurane exposure during repeated imaging. Stroke outcome evaluation was conducted in a blinded fashion. Following MCAO and sham surgery, subjects were randomly assigned to intended treatment groups and given a new ID by a person that was not involved in surgery,

course for flow velocity, vascular diameter, and flux of $d b /+$ and $d b / d b$ mice representing each segment are shown as $\boldsymbol{B}$ (segment 1), $\boldsymbol{C}$ (segment 2), and $\boldsymbol{D}$ (segment 3). At baseline, there was no significant difference in flow velocity, vascular diameter, or flux between $d b / d b$ and $d b /+$ mice. However, following MCAO, there was a significant decrease in the retrograde flow in the $d b / d b$ mice compared with $d b /+$ mice, particularly at segments proximal to MCA, leading to a significantly reduced flux in $\operatorname{Seg} 3$ in $d b / d b$ mice. $N=9-11$ / group. $\boldsymbol{E}$, Representative DOCT images of $d b /+$ and $d b / d b$ mice at baseline, during reperfusion, and at $7 \mathrm{~d}$ after stroke. Arrow indicate significant collateral remodeling in both strains of mice. Changes in velocity, diameter, and flux in segment 1 $(\boldsymbol{F})$, segment $2(\boldsymbol{G})$, and segment $3(\boldsymbol{H})$ between reperfusion and $7 \mathrm{~d}$ after MCAO were plotted in line graphs $(N=3$ or $4 /$ group). Although there was an overall improvement of perfusion following reperfusion in both strains of mice, $d b / d b$ mice continued to display deficit in collateral perfusion. At $7 \mathrm{~d}$ after MCA0, flow velocity was significantly reduced in all segments of MCA branches of $d b / d b$ mice compared with that of $d b /+$ mice. ${ }^{*} p<0.05 .{ }^{* *} p<0.01$. Scale bar, $1 \mathrm{~mm}$. Base, baseline; Occ, occlusion; Rep, reperfusion. 
E
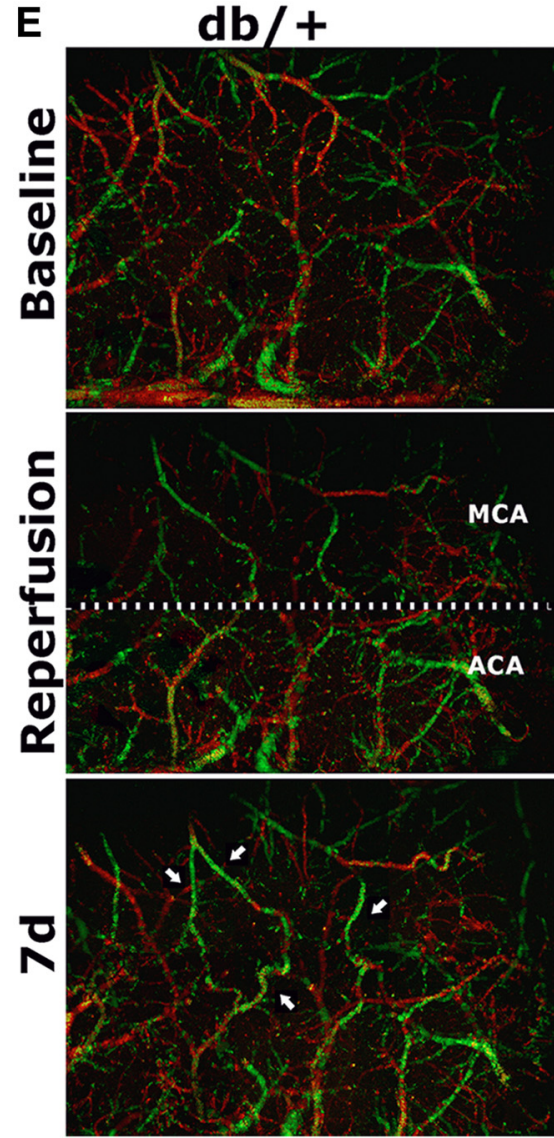

$\mathbf{F}$
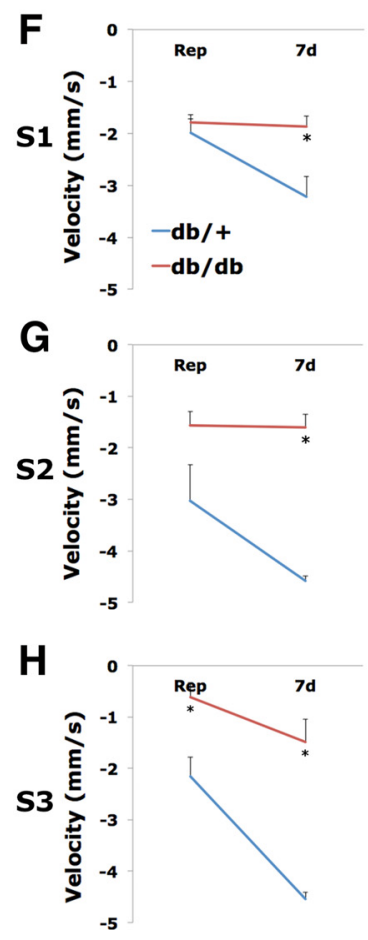
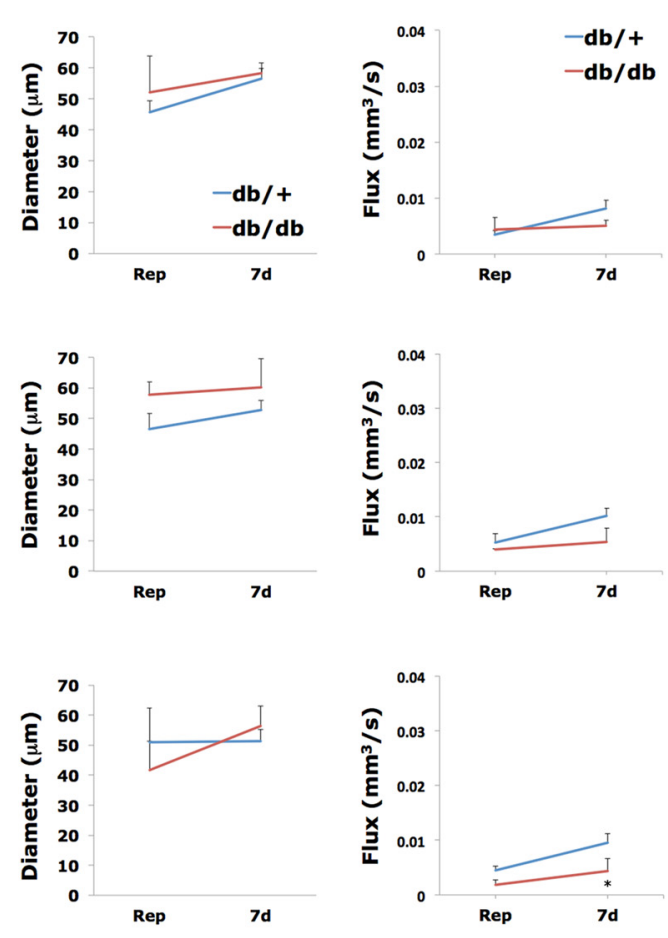

Figure 3. Continued $\mathbf{d b} / \mathbf{d b}$
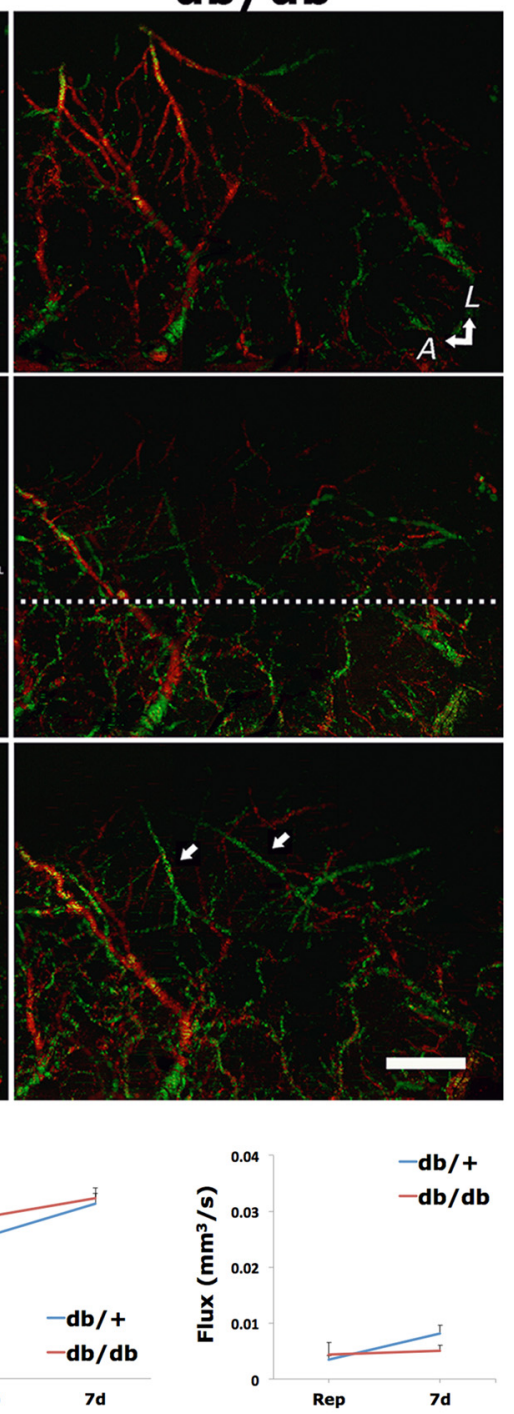

ladder was videotaped and the percentages of footfalls (slipping through the bars) with the affected forelimb were scored and averaged in 3 trials (Sun et al., 2013).

Corner test. A mouse was placed halfway to the corner between two boards each with dimension of $30 \times 20 \times 1 \mathrm{~cm}^{3}$ at a $30^{\circ}$ angle, arranged with a small opening along the joint between the boards to encourage exploration into the corner. When entering deep into the corner, both sides of the vibrissae approached the wall. The mouse soon reared forward and upward, then turned back to face the open end. The nonischemic mouse turned left or right with equal frequency, but mouse with unilateral ischemic injury preferentially turned toward the nonimpaired, ipsilateral side (left in our model). The number of turns in each direction was summed from 10 trials. Turning movements that were not a part of a rearing movement were not scored (Zhang et al., 2002).

Infarct volume assessment. Seven days after stroke, $40-\mu \mathrm{m}$-thick coronal sections were collected serially with a periodicity of 6 after transcardiac perfusion with $4 \%$ PFA as described previously (Raber et al., 2004). Infarct volume was measured by subtracting the volume of intact tissue in the ipsilateral hemisphere from that in the contralateral hemisphere on Nissl-stained serial sections ( $240 \mu \mathrm{m}$ apart) by ImageJ (Version 1.3, National Institutes of Health) (Sun et al., 2013). Percentage infarction was determined by dividing infarct volume with total brain volume.

Statistical analysis. Data were expressed as mean \pm SEM and analyzed by one-way, twoway ANOVA, or RANOVA using Statview 4.01 (SAS Institute) with Bonferroni corrections for multiple comparisons when appropriate. $p$ values $<0.05$ were considered significant.

\section{Results}

Temporal progression and growth of leptomeningeal collateral flow following ischemic stroke

Using DOCT, a reversal of MCA flow direction was observed, which is referred to as retrograde flow, contrary to the anterograde flow direction at baseline (Fig. $2 A, B)$. Tortuous collateral anastomoses connecting the distal MCAs and ACAs became apparent after MCAO (Fig. 2B). At baseline, a decreasing gradient in flow velocity and flux was detected from proximal to distal MCAs (Fig. 2A,E,H,J), whereas the diameter remained constant (Fig. 2I). After MCAO, there was a general reduction in flow velocity and flux (Fig. $2 B, F, H, J)$.

To increase the accuracy of comparison, MCA branches downstream of the

drug injection, or later evaluation (histological and behavioral assessment).

Horizontal ladder test. Mice were trained to cross a 2-foot-long inclined ladder with variable spacing between bars ranging from 1 to $4 \mathrm{~cm}$ that placed at a $15^{\circ}$ angle for 3 consecutive trials. The performance on occlusion point were categorized according to branching order, in which segment 1 (Seg 1) is most proximal to ACA while most distal to MCA; Seg 3 is the proximal MCA branch relative to Seg 2 and most distal to ACA (Fig. 2G). During MCAO, Seg 
1, Seg 2, and Seg 3 slowed down to 56\%, 31\%, and 13\% of their baseline velocities, respectively. Thereafter, flow velocity in Seg 3 was significantly increased at $24 \mathrm{~h}$ and $7 \mathrm{~d}$ after MCAO $(p<0.05$ and $p<0.005$, respectively) (Fig. $2 C, D, H)$. There was also a concurrent increase in MCA diameter of Seg 1 at $7 \mathrm{~d}$ after MCAO relative to baseline or during MCAO $(p<0.05$ and $p<0.01$, respectively), although it did not change significantly at the other acute time point (Fig. 2I). Similar to flow velocity, flux decreased during MCAO but increased at $7 \mathrm{~d}$ after MCAO in Seg $3(p<0.001)$ (Fig. $2 J)$.

\section{$\mathrm{db} / \mathrm{db}$ mice exhibit impaired recruitment of leptomeningeal collateral flow and a more severe stroke outcome}

Baseline physiological assessment showed that the concentration of blood glucose and body weight were significantly greater in $d b / d b$ mice than their normoglycemic, age-matched counterparts, $d b /+$ mice (Table 1), consistent with the effect of insulin tolerance. Consistent with previous findings (Li et al., 2013), $\mathrm{db} / \mathrm{db}$ mice exhibited slightly higher blood pressure during MCAO (db/db: $92.5 \pm 6.5 \mathrm{mmHg} ; d b /+: 81.8 \pm 3.4 \mathrm{mmHg} ; p<$ $0.05)$. Baseline flow velocity, diameter, and flux did not differ between the two genotypes (Fig. $3 A-D$ ). However, retrograde filling of MCA from ACA was much reduced in $d b / d b$ compared with $d b /+$ mice during MCA occlusion, with significantly slower flow velocity in all segments quantified (Fig. $3 A-D$ ). There was no significant difference in diameter between groups in each segment during acute stages after MCAO. Similar to flow velocity, flux in Seg 3 was also significantly reduced in $d b / d b$ mice during and after MCAO $(p<0.05)$, suggesting that the collateral flow recruitment was impaired in $d b / d b$ strain, particularly at proximal MCA branches. The collateral flow impairment observed in the $d b / d b$ mice appears to persist chronically as shown in a subsequent study during chronic stroke (Fig. 3E-H). Despite the growth of collateral flow and vessels at $7 \mathrm{~d}$ after MCAO in both strains of mice, the flow velocity of all segments was significantly reduced in the $d b / d b$ mice compared with $d b /+$ mice (Fig. $3 E-H$ ). Relative to $d b /+$ mice, the retrograde flow of $d b / d b$ mice in segment 3 after MCAO was significantly diminished at all time points examined (Fig. 3).

The impaired collateral status was correlated with significantly worse stroke outcomes in infarct size $(p<0.01$; Fig. $4 A)$, and motor function (horizontal ladder test: $p<0.01$; Fig. $4 B$; corner test: $p<0.05$; Fig. $4 C$ ) assessed $7 \mathrm{~d}$ after MCAO in the $d b / d b$ mice compared with $d b /+$ mice. The worse stroke outcome in diabetic mice is consistent with the larger lesion size and worse National Institutes of Health stroke scale or modified Rankin scale seen in human stroke patients with hyperglycemia (Parsons et al., 2002).

To rule out the potential contribution of genetic variation in cerebrovasculature (Majid et al., 2000; Liu et al., 2014), we performed DiI arterial labeling in $d b /+$ and $d b / d b$ mice as described previously (Li et al., 2008). No significant difference was observed in the number of collaterals interconnecting ACA and MCA (Fig. $5 A, B)$, distance of ACA and MCA anastomoses to midline (Fig. $5 C$ ), or patency of the PcomA (Fig. 5D). Moreover, to determine the delayed effect of stroke on collateral interconnectivity, we quantified the number of MCAs perfused retrogradely via the ACA in the ipsilateral hemisphere $7 \mathrm{~d}$ after MCAO. Compared with $d b / d b$ mice, the $d b /+$ mice developed significantly more dilated tortuous collateral anastomoses around the border zone between ACA and MCA in the ipsilateral hemisphere (Fig. 5A, arrowhead), a sign of reduced axial tension due to increased blood flow and associated elastin degradation (Do- brin et al., 1988; Hoi et al., 2008). In contrast to $d b /+$ mice, $d b / d b$ mice had fewer perfused leptomeningeal collaterals between MCA and ACA at 1 week following MCAO (Fig. 5A, B) $(p<0.05)$.

\section{Acute hyperglycemia alone is insufficient to cause impairment in collateral flow recruitment}

To determine whether the impaired collateral recruitment observed in the T2DM stroke mice is attributable to hyperglycemia per se, we infused dextrose solution $60 \mathrm{~min}$ before the induction of stroke in $d b /+$ mice, who shared a great deal of genetic similarity in cerebrovasculature and collateral anatomy with the $d b / d b$ strain. The dose-titration study determined the optimal amount of dextrose to be $1.25 \mathrm{~g} / \mathrm{kg}$ ( $5 \mathrm{ml} / \mathrm{kg}$ of $25 \%$ solution), to match the blood glucose level of the $d b / d b$ mice at $\sim 380 \mathrm{mg} / \mathrm{dl}$ (Fig. 6A). There was no significant difference in glucose metabolism after intraperitoneal injection of dextrose solution at the chosen dose between $d b /+$ and wild-type mice (RANOVA: $F_{(1,32)}$ $=0.17, p>0.68)($ Fig. $6 B)$, suggesting that $d b /+$ mice are indeed an appropriate strain for study of acute hyperglycemia. Time course study showed that blood glucose level of the inducedhyperglycemic $d b /+$ was maintained at comparable levels during stroke and imaging relative to the $d b / d b$ mice (Fig. $6 C$ ). There was a tendency for the blood glucose to increase after MCAO in all groups, although there were no significant differences when compared with respective pre-MCAO glucose levels (Fig. 6C). Blood glucose level returned to the normal range at $24 \mathrm{~h}$ after MCAO in the $d b /+$ mice. Despite that $d b / d b$ mice experienced a temporary reduction in blood glucose level at $24 \mathrm{~h}$ after MCAO possibly due to reduced food intake, they have gradually resumed their hyperglycemic state $2 \mathrm{~d}$ later (Fig. 6C).

Similar to $\mathrm{C} 57 \mathrm{BL} / 6$ mice, MCA flow direction in the $d b /+$ mice was reversed in all measured MCA segments in both normoglycemic and hyperglycemic groups (Fig. 7A). There were no significant differences in flow velocity, vessel diameter, and flux between groups during baseline or MCAO (Fig. 7A-D), suggesting that temporarily induced hyperglycemia was not sufficient to impact collateral flow dynamics.

\section{Human albumin augments collateral perfusion and reduces infarct size in $d b / d b$ mice}

To determine the effect of albumin on collateral flow following ischemic stroke, albumin or saline was infused intravenously at $150 \mathrm{~min}$ after MCAO, or $60 \mathrm{~min}$ after CCA reperfusion. Collateral flow was imaged before and after treatment, corresponding to 30 and $90 \mathrm{~min}$ after ischemic reperfusion, respectively (Fig. $8 A$ ). Before treatment, flow velocity and flux in the $d b / d b$ group were significantly slower in each segment compared with that in the $d b /+$ group (velocity: Seg $1 / \operatorname{Seg} 2 / \operatorname{Seg} 3: p<0.05 / p<0.01 /$ $p<0.01$; flux: Seg 1/Seg 2/Seg 3: $p<0.05 / p<0.05 / p<0.05$ ) (Fig. $8 B, C, E)$. However, there was no significant difference in the diameter in any segment between groups (Fig. 8D).

Albumin significantly improved collateral flow recruitment in the diabetic mice (Seg 1 and $-3: p<0.05$, Seg 2: $p<0.01$, respectively), particularly in proximal MCAs (Fig. $8 F$ ). There was no significant difference in relative diameter change between saline and albumin treatments, although MCA diameter in all segments had a tendency to decrease slightly at $30 \mathrm{~min}$ after saline or albumin treatment in $d b / d b$ mice (Fig. $8 G$ ). There were also significant relative flux improvement following albumin compared with saline treatment in Seg 2 and Seg 3 (Seg 2: $p<0.005$; Seg 3: $p<0.05)$ (Fig. $8 H$ ). The relatively greater improvement in veloc- 
A

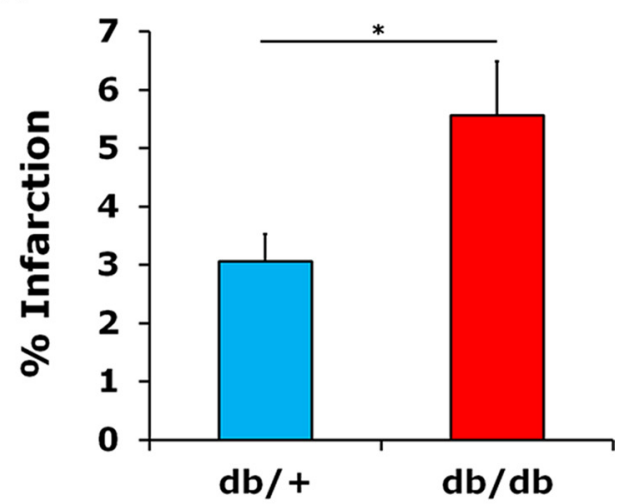

B
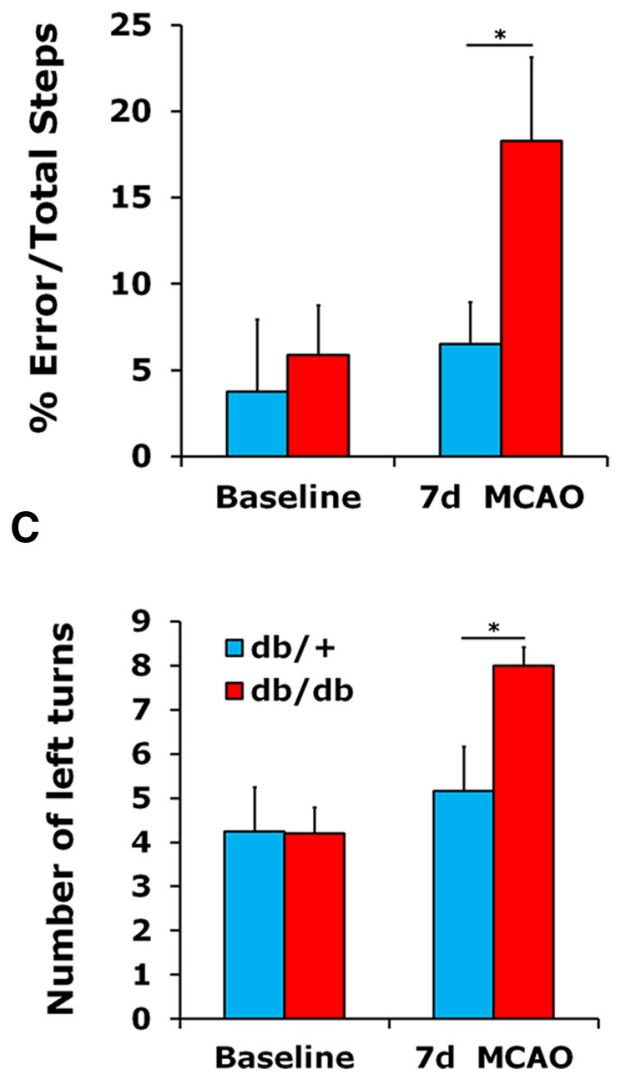

Figure 4. Effect of $M C A 0$ on stroke outcome in $d b /+$ and $d b / d b$ mice. Infarct volume $(A)$ and neurobehavioral outcome $(\boldsymbol{B}, \boldsymbol{C})$ in $d b / d b$ mice were compared with $d b /+$ mice at $7 \mathrm{~d}$ after stroke. $\boldsymbol{A}, d b / d b$ mice sustained a significantly larger stroke size compared with $d b /+$ mice. $\boldsymbol{B}$, $d b / d b$ mice slipped through the bars more frequently when traversing an elevated horizontal ladder compared with $d b /+$ mice at $7 \mathrm{~d}$ after stroke. $C, d b / d b$ mice also made significantly more ipsilateral turns in the corner test compared with $d b /+$ mice, reflecting a more pronounced functional impairment in sensorimotor asymmetry. At $7 \mathrm{~d}$ after stroke, $d b /+$ mice showed considerable recovery in motor function with the distal occlusion model of stroke. ${ }^{*} p<0.05$. $N=5$ or $6 /$ group.

ity and flux in the proximal MCA branches suggests that retrograde flow from ACA was able to reach a longer distance following albumin treatment. Surprisingly, the relative flow velocity increase in $d b /+$ mice following albumin treatment was less pronounced and insignificant relative to saline treatment. Besides, unlike the $d b / d b$ mice, there was no preferential increase of relative velocity in the segments distal to ACA in the $d b /+$ mice, due to an already sound collateral recruitment in the absence of treatment in the latter strain. Relative diameter change also did not differ significantly between treatments in the $d b /+$ mice. However, saline significantly reduced the MCA diameter in $d b / d b$ mice compared with $d b /+$ mice (Fig. $8 G$ ). There was no significant difference in relative flux change between two treatment groups in the $d b /+$ mice due to a minor improvement in flux after either treatment (Fig. $8 H$ ). These results suggest that albumin was effective in improving leptomeningeal collateral flow after MCA stroke in the $d b / d b$ mice, with the retrograde flow reaching proximal to the occlusion point in the MCA territory.

At $7 \mathrm{~d}$ after stroke, $d b / d b$ mice receiving albumin treatment exhibited significantly smaller infarct volume compared with those receiving saline (albumin vs saline: $3.4 \pm 0.4 \%$ vs $5.0 \pm$ $0.4 \%, p<0.05)$. Despite a significant overall effect of albumin on neuroprotection (two-way ANOVA, albumin effect: $F_{(1,18)}=9.2$, $p<0.01$ ), albumin did not effectively reduce stroke size in the $d b /+$ mice $(1.9 \pm 0.4 \%$ vs $3.0 \pm 0.5 \%$, not significant $)$, suggesting a ceiling effect (Fig. 8I).

\section{Discussion}

We demonstrated that the leptomeningeal collateral anastomoses provided rapid and persistent perfusion to ischemic territories following MCAO. Furthermore, the collateral blood flow continued to increase over $7 \mathrm{~d}$ after MCAO with a considerable degree of vascular remodeling as evidenced by the increased diameter of collateral vessels in wild-type mice. In contrast, $d b / d b$ mice had impaired collateral flow recruitment after MCAO compared with $d b /+$, particularly at proximal MCA where the retrograde flow failed to reach, despite the similarity in baseline flow velocity and vascular anatomy between the two genotypes. The slower flow velocity from ACA to proximal MCA observed in $d b / d b$ mice following stroke likely contributed to the inadequate retrograde filling of the MCA closest to the site of occlusion, where it was needed most. Consistent with this finding, $d b / d b$ mice sustained a larger stroke size and poorer neurological outcome $7 \mathrm{~d}$ after MCAO. Despite the chronic collateral remodeling in both strains of mice, $d b / d b$ mice still exhibited significantly reduced flow velocity in all segments at $7 \mathrm{~d}$ after stroke compared with $d b /+$ mice. However, temporarily induced hyperglycemia in the genetically related strain $d b /+$ did not have an adverse effect on collateral flow recruitment before and after stroke, suggesting that chronic pathological modification of the cerebrovasculature in the diabetic mice rather than acute hyperglycemia alone might have contributed to the observed impairment of collateral flow in the $d b / d b$ mice. Moreover, albumin treatment significantly improved retrograde filling particularly at proximal MCA after stroke and reduced infarct volume in the $d b / d b$ mice. The beneficial effect of albumin was less prominent in the $\mathrm{db} /+$ mice in which a robust collateral status already existed.

As DOCT is best suited to measure blood flow within the top $150 \mu \mathrm{m}$ of the brain in relatively larger vessels, it not only is an ideal imaging modality for studying dynamic flow changes in leptomeningeal anastomoses in rodents after MCA stroke or chronic hypoperfusion but also provides a great improvement over previous methodologies for visualizing spatiotemporal blood perfusion in the cortex following stroke. Our result using DOCT demonstrated, for the first time, that the collateral recruitment was immediate via anastomotic connections between ACA and MCA, complementing previous studies using other optical imaging techniques (Shih et al., 2009; Armitage et al., 2010). Contrary to the dilation of cerebral arteries found during acute stroke in some studies (Armitage et al., 2010), the average arterial diameter 
A

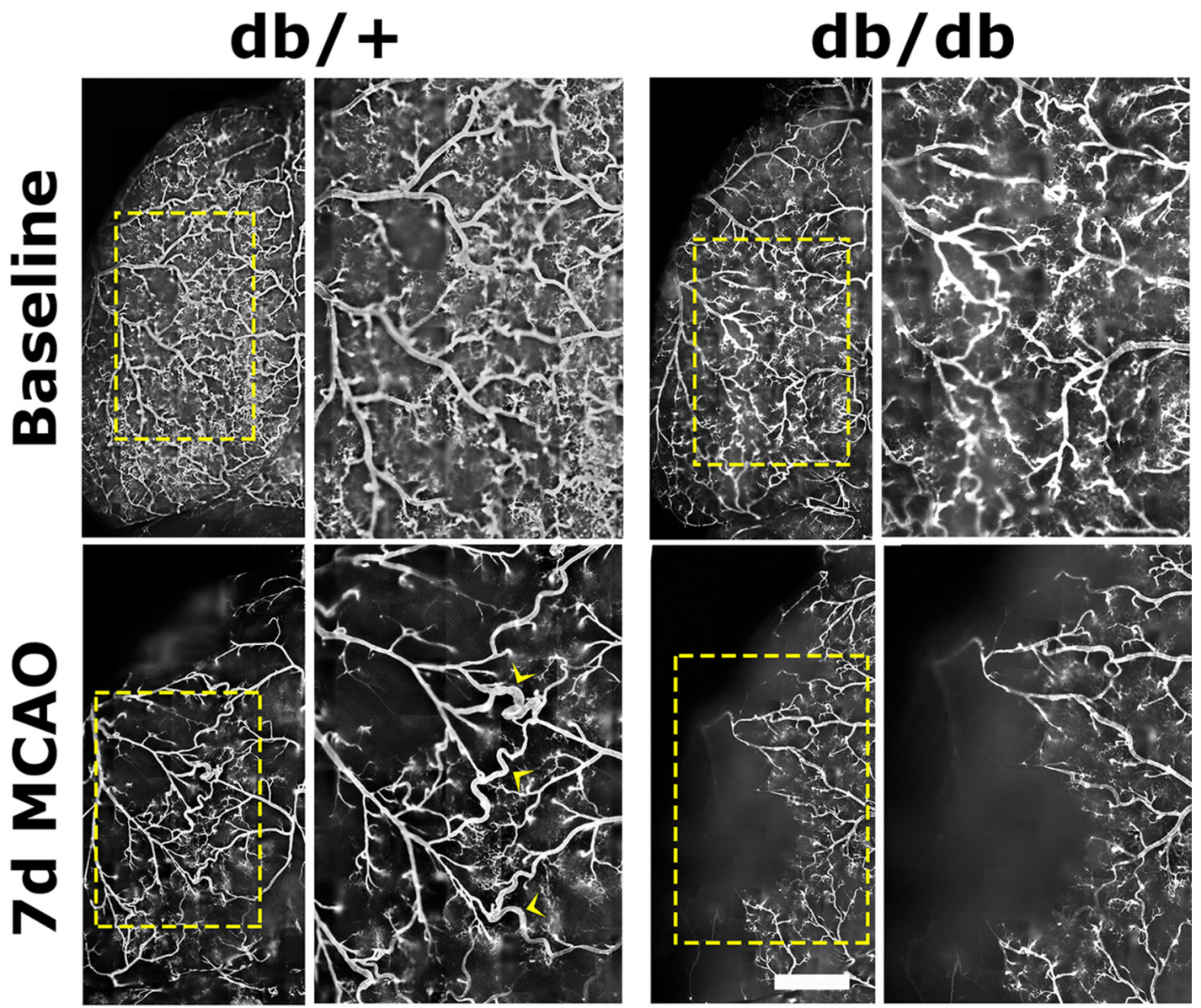

B

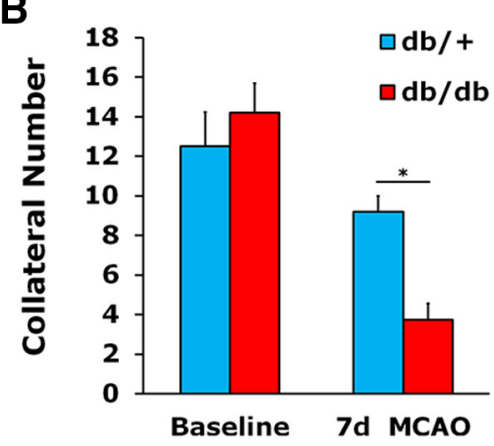

C

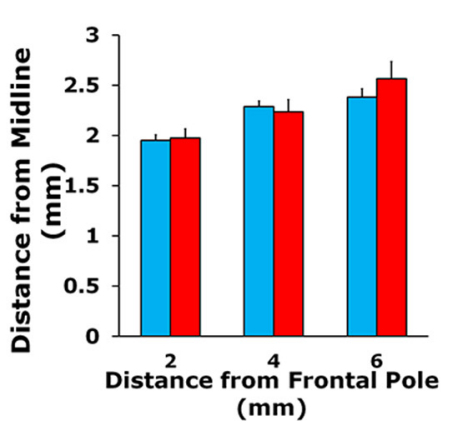

D

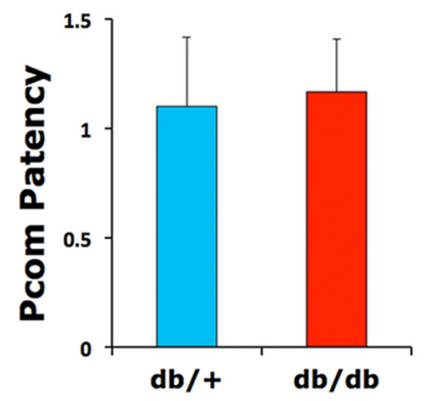

Figure 5. $d b / d b$ mice share a similar extent of leptomeningeal anastomoses between MCA and ACA, size of MCA territory, and the patency of posterior communicating arteries (Pcom) with $d b /+$ mice. $A$, Arteriograms of $d b /+$ and $d b / d b$ mice at the dorsal view via Dil labeling. Enlarged views of the yellow insets revealed the connecting points between MCA and ACA vascular networks. At $7 \mathrm{~d}$ after MCA0, the diameter of the collateral vessels in the $\mathrm{db} /+$ mice increased to accommodate more collateral flow with increased tortuosity (yellow arrowheads). $\boldsymbol{B}$, The number of connecting collaterals between MCA and ACA was quantified following Dil perfusion at baseline and $7 \mathrm{~d}$ after MCA0. $\mathrm{db} / \mathrm{db}$ mice had a similar number of perfused collaterals at baseline, but a lower number of perfused collaterals at $7 \mathrm{~d}$ after MCAO compared with $\mathrm{db} /+$ mice, suggesting a functional impairment of collateral recruitment rather than a structural deficiency in the collateral circulation. C, There was no significant difference between two groups of mice at baseline in the distance between midline and the line of anastomoses between the ACA and MCA as determined by the Dil arterial labeling. $D$, There was also no significant difference in the PcomA patency between groups, suggesting that both strains of mice shared a similar degree of primary collateral circulation. ${ }^{*} p<0.05 .5$ cale bar, $1 \mathrm{~mm}$. $N=5$ or $6 / \mathrm{group}$.

remained constant in our study. One possible explanation for this apparent discrepancy may be due to the relatively large arteries (diameter: $50-60 \mu \mathrm{m}$ ) evaluated in our study, supported by a previous finding that vasodilation occurred in small penetrating and surface arterioles $(<23 \mu \mathrm{m})$ during focal cerebral ischemia, but not in large surface arteries (23-60 $\mu \mathrm{m}$ ) (Shih et al., 2009). However, we found that arteries at distal MCA segments increased in diameter and flow velocity during chronic reperfusion, suggesting the presence of vasodilation and/or vascular remodeling. Consistent with this notion, a previous study reported that $\mathrm{db} / \mathrm{db}$ mice exhibited hypertension, greater stroke size, worse neurological outcome after MCAO, impaired vascular reactivity, and reduced eNOS phosphorylation, and that phosphomimetic eNOS SD knock-in mutation corrected the above impairment (Li et al., 2013).

Albeit nonperfusion mechanisms were reported to underlie the worse ischemic brain damage among diabetic subjects (Chen et al., 2011; Kumari et al., 2011), our data clearly indicated that collateral flow recruitment was impaired specifically at proximal 


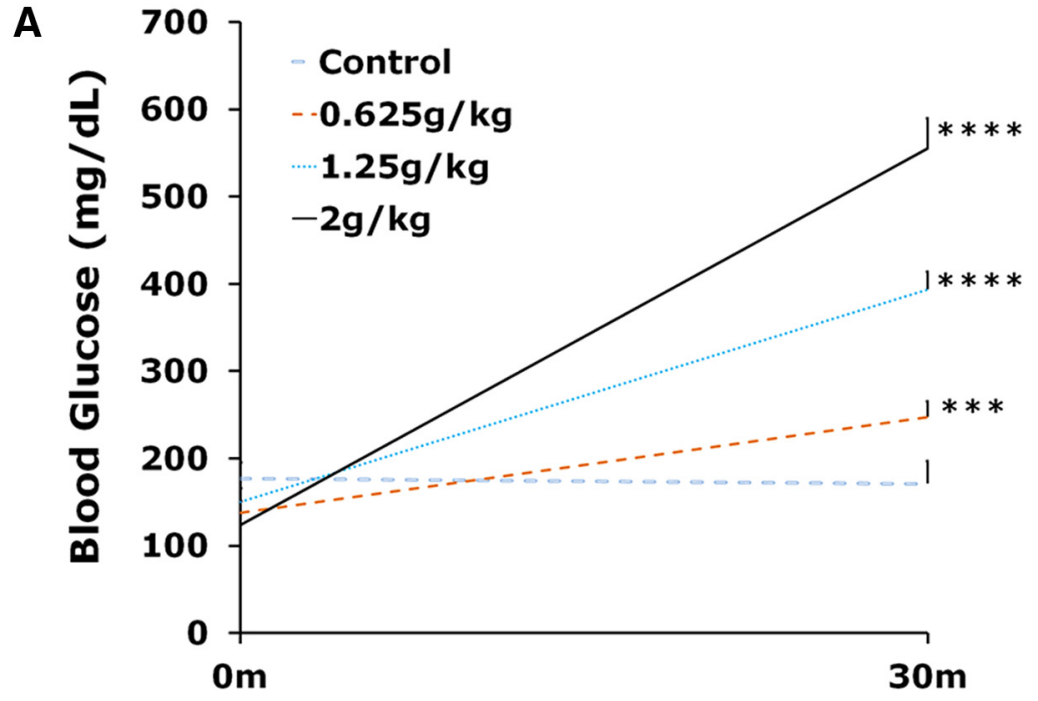

B
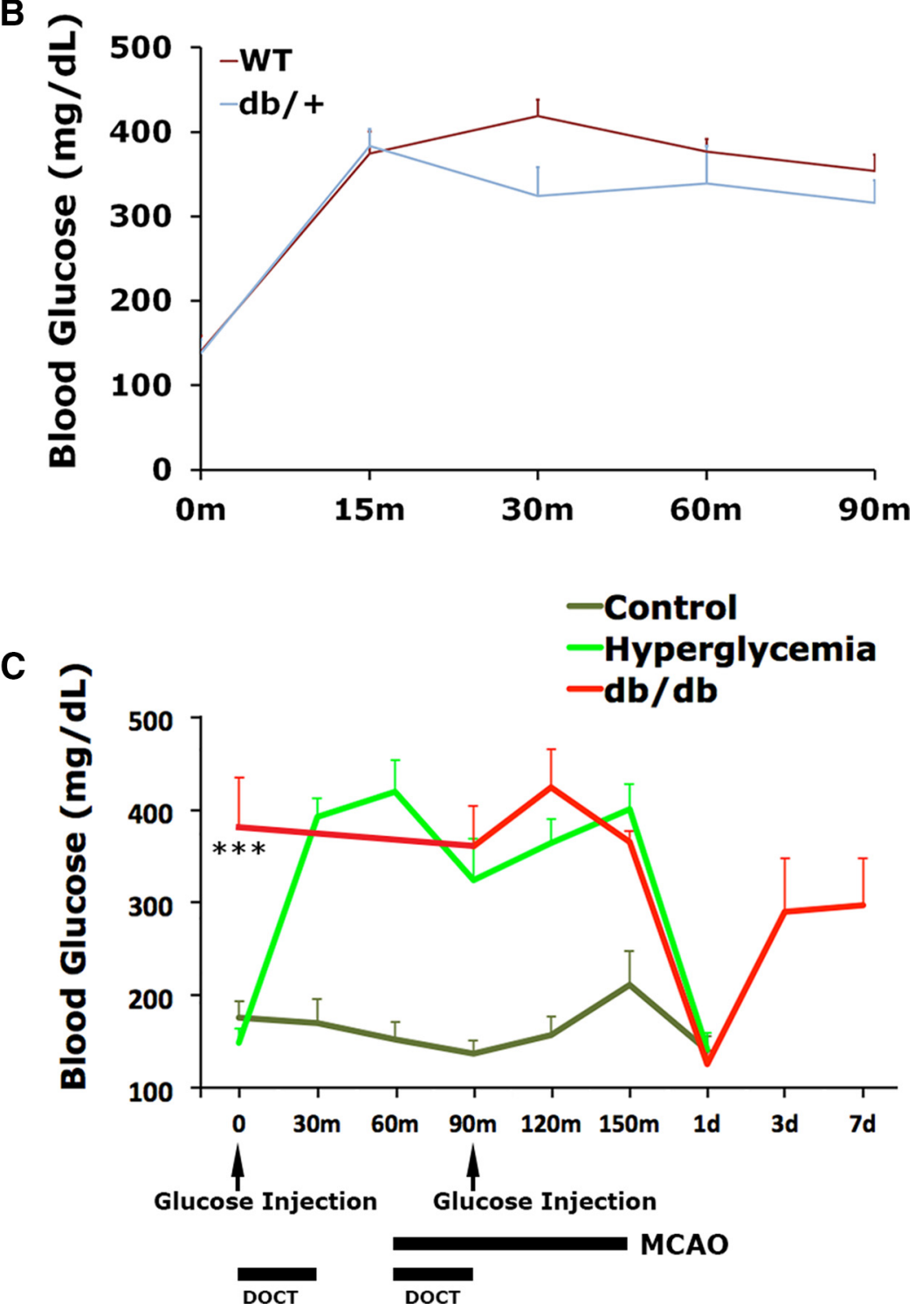

Figure 6. Induction of hyperglycemia by glucose in the $d b /+$ mice. $\boldsymbol{A}$, There was a dose-dependent rise of blood glucose following intraperitoneal injection of $25 \%$ dextrose solution at various doses. The $1.25 \mathrm{~g} / \mathrm{kg}$ dose produced a blood concentration of glucose in the $d b /+$ mice similar to age-matched $d b / d b$ mice. $\boldsymbol{B}$, Comparison of blood glucose metabolism between $d b /+$ and
MCA in $d b / d b$ compared with $d b /+$ strain, despite their similar baseline flow value and anatomical collateralization. As the contributing factors leading to the impaired collateral flow recruitment in the $d b / d b$ mice remain uncertain, vascular effects, including eNOS-dependent vasodilation, may not be the sole basis for the impaired collateral flow dynamics in this model. Given the fact that the plasma concentration and activity of plasminogen activator inhibitor-1 (PAI-1), a potent endogenous tPA inhibitor, are heightened in T2DM, which might lead to increased formation of occlusive thrombi after vascular injury and thus could in part contribute to the impaired collateral status seen in the $d b / d b$ mice during stroke (Alessi and Juhan-Vague, 2006; Trost et al., 2006; Grant, 2007). This is also consistent with the fact that collateral flow was impaired specifically at proximal MCA in $d b / d b$ mice because the reduced endogenous thrombolytic activity associated with diabetes failed prematurely along the way in the retrograde flow, leading to unsuccessful perfusion of MCA branches distal to the anastomosis point (Caplan and Hennerici, 1998). Furthermore, the advanced glycation end products, which play an important role in diabetic vascular complications, are implicated in the upregulation of PAI-1 in vascular endothelial cells through the interaction with the receptor for advanced glycation end products (Sangle et al., 2010). It has also been shown in patients with cardiovascular disease and diabetes that pathological increases of platelet hyperreactivity, plasma viscosity, fibrinogen concentration, PAI concentration, as well as red blood cell aggregation are of major rele-

\section{$\leftarrow$}

wild-type littermates during the course of 90 min after glucose administration at $1.25 \mathrm{~g} / \mathrm{kg}$. There was an identical rise of blood glucose at $15 \mathrm{~min}$ and a similar fall of blood glucose over the course of 90 min after injection between two strains of mice. Apart from the similarity in collateral anatomy between $d b /+$ and $d b / d b$ mice, the normal glucose metabolism observed in the $d b /+$ mice further supports the appropriateness of this strain as the candidate in studying the role of hyperglycemia in collateral flow recruitment during stroke. C, Blood glucose level before, during, and after MCAO in $d b / d b$, hyperglycemic, and control $d b /+$ mice. Despite a more severed ischemic injury following MCAO in the $d b / d b$ mice, there was no significant difference in blood glucose level between $d b / d b$ and the hyperglycemic $d b /+$ mice. Furthermore, blood glucose concentration in the hyperglycemic $d b /+$ mice returned to the normal level at $24 \mathrm{~h}$ after stroke, similar to that of control $d b /+$ mice. The $d b / d b$ mice gradually resumed their hyperglycemic state after a temporary reduction of blood glucose level at $24 \mathrm{~h}$ after stroke. ${ }^{* * *} p<0.005 .{ }^{* * * *} p<0.001 . N=$ 6 or $7 /$ group. 
A

Control

Hyperglycemia
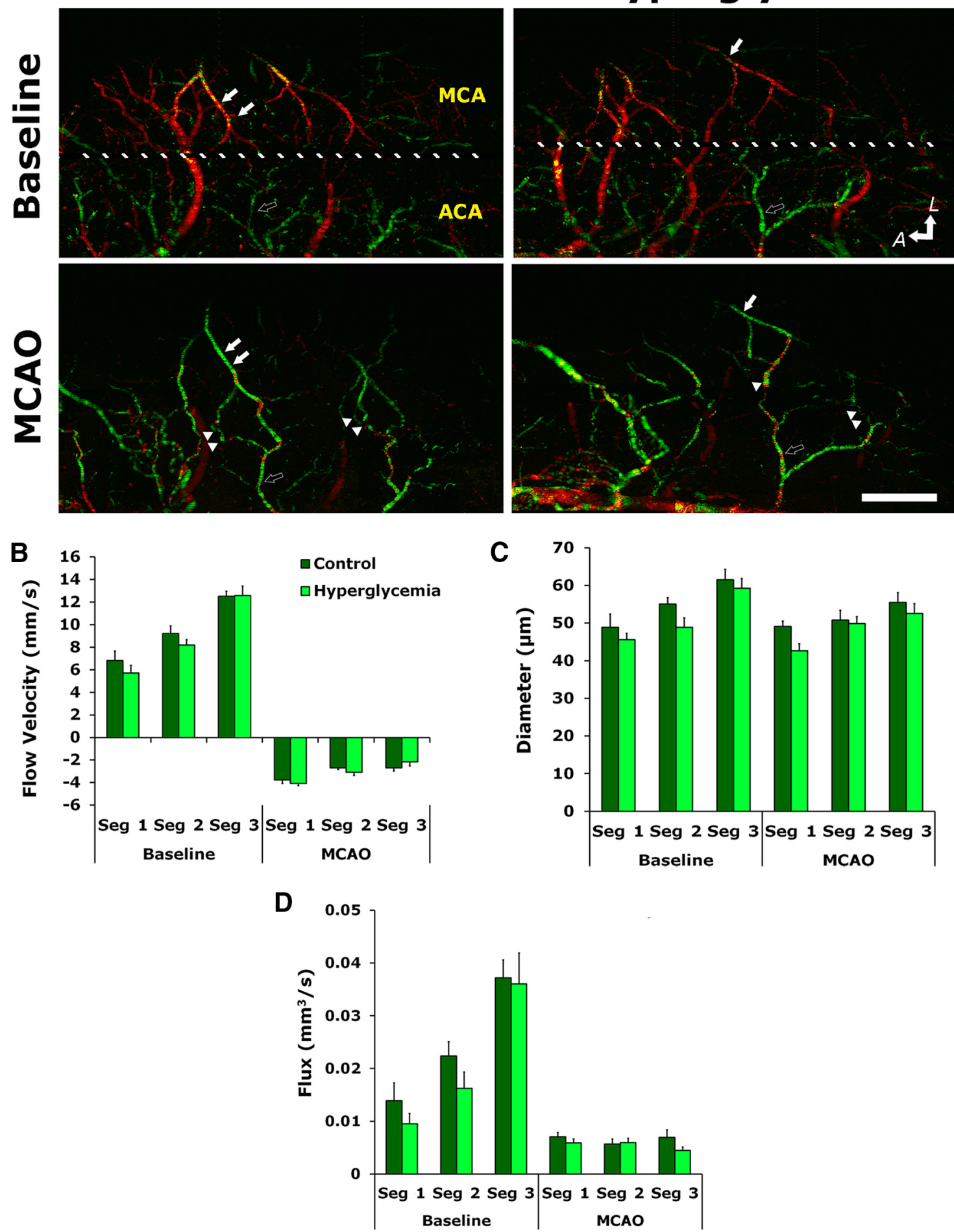

Figure 7. Acutely induced hyperglycemia does not impair leptomeningeal collateral recruitment during stroke in the $d b /+$ mice. Hyperglycemia was induced by glucose injection at 60 min before the onset of MCAO and maintained by a booster injection at $30 \mathrm{~min}$ after MCAO. A, Representative DOCT images of hyperglycemic and normoglycemic control mice at baseline and during MCA0. Dotted white lines indicate the divide between MCA and ACA territory The anatomic orientation of the brain is indicated with arrows pointing to the lateral $(L)$ and anterior $(A)$ directions. Arrows indicate the robust retrograde flow (green) reached at proximal MCA branches during MCA 0 in both control and hyperglycemic $d b /+$ mice. Corresponding positions at baseline were labeled with arrows for comparison. Arrowheads indicate the tortuous collateral vessels recruited during MCA0. Quantitative data of flow velocity $(\boldsymbol{B})$, diameter $(\boldsymbol{C})$, and flux (D) suggest that there was no significant difference in the flow dynamics and functional arterial diameter between hyperglycemic and control db/ + mice at baseline and during MCAO. Scale bar, $1 \mathrm{~mm} . N=6$ or $7 / \mathrm{group}$.

vance for the short-term incidence of ischemic events due to the procoagulant and prothrombotic states (Thompson et al., 1995).

Contrary to the similar number of leptomeningeal connecting collaterals found between $d b / d b$ and $d b /+$ mice in our study, the collaterals between MCA and ACA or PCA were significantly increased in 10-week-old GK rats, a lean model of spontaneous Type 2 diabetes (Goto et al., 1976) with moderately elevated glucose levels, compared with control (Li et al., 2010). The increased 
A

reperfusion injection

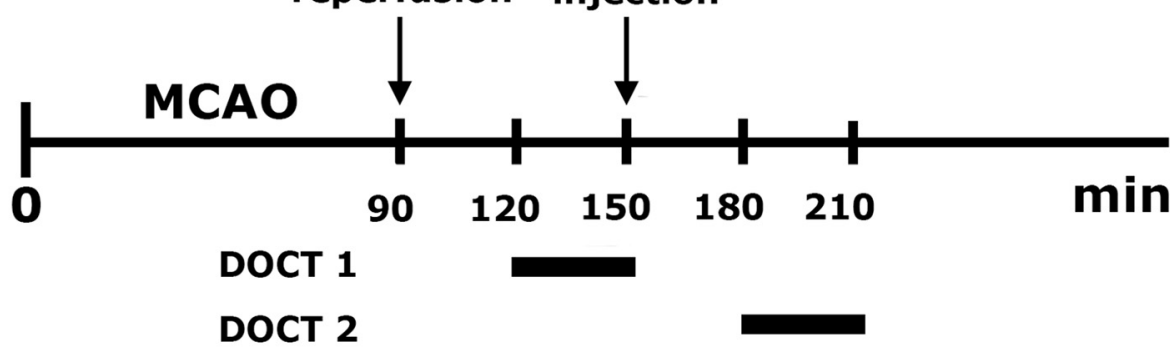

B
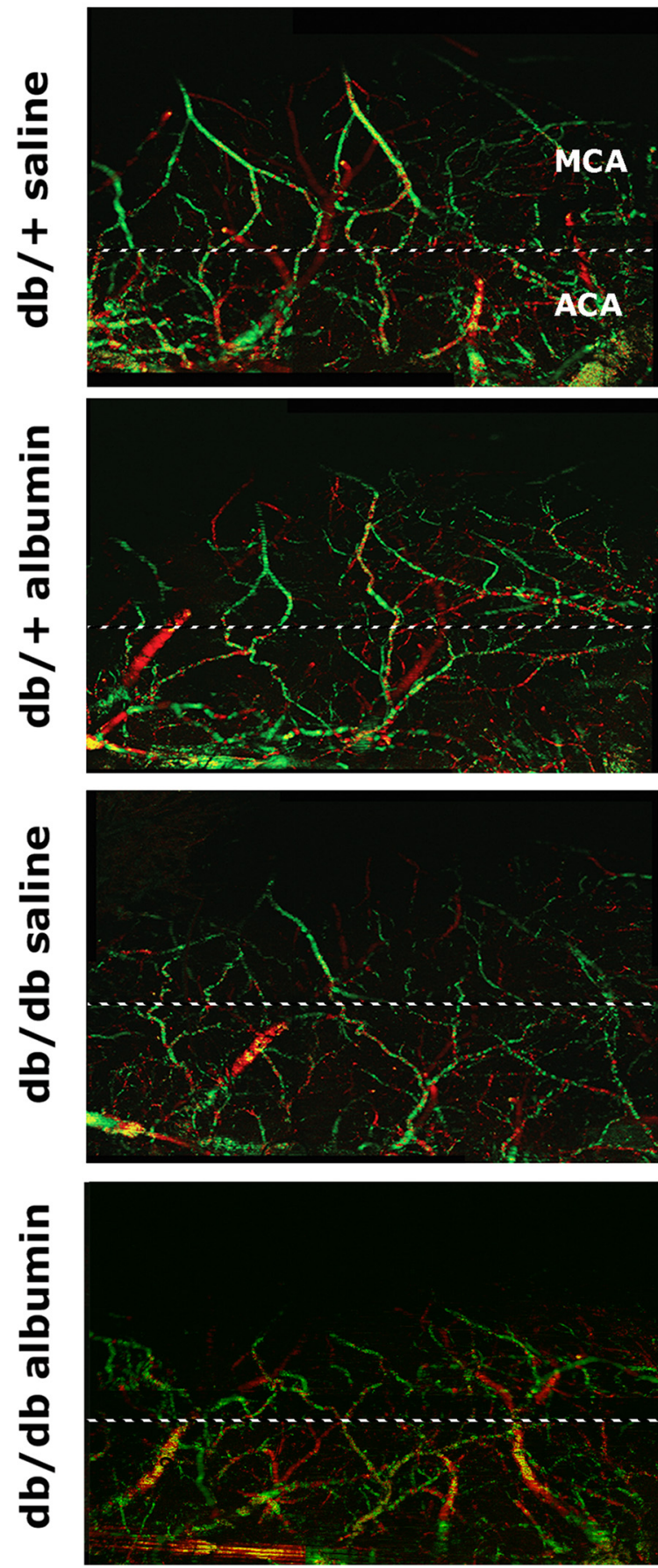

DOCT 2
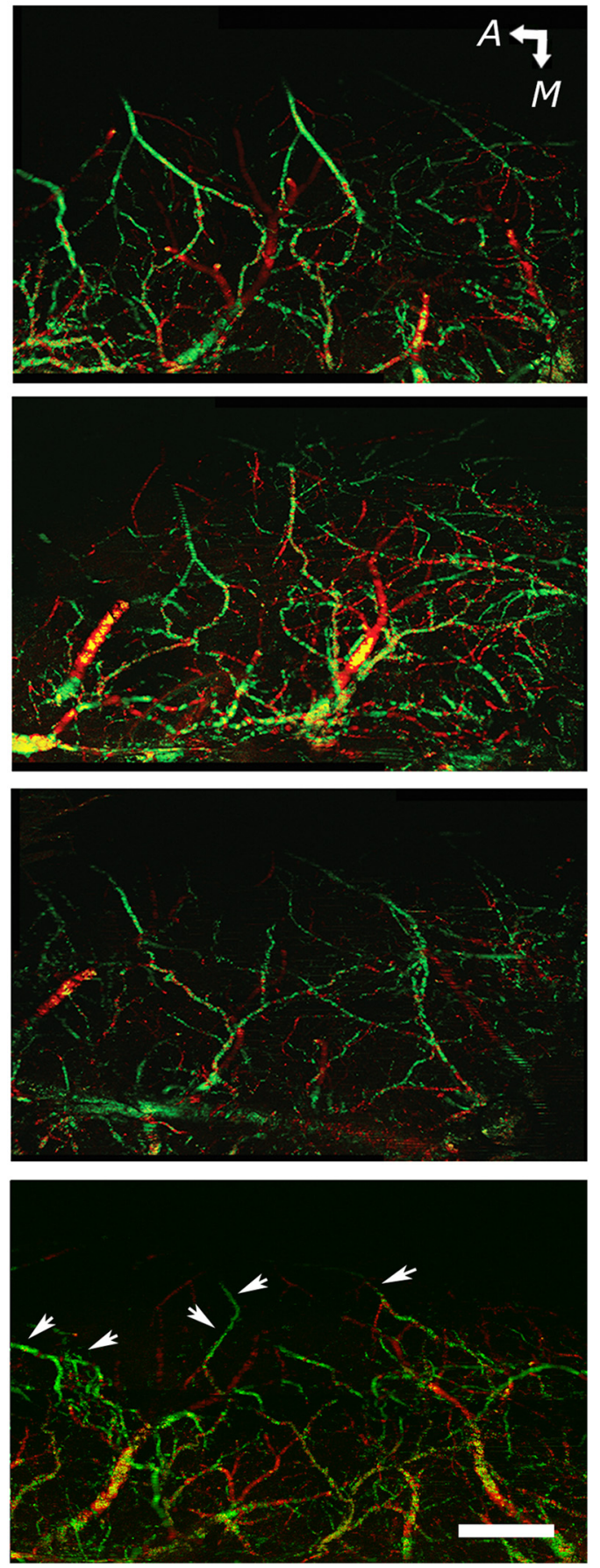

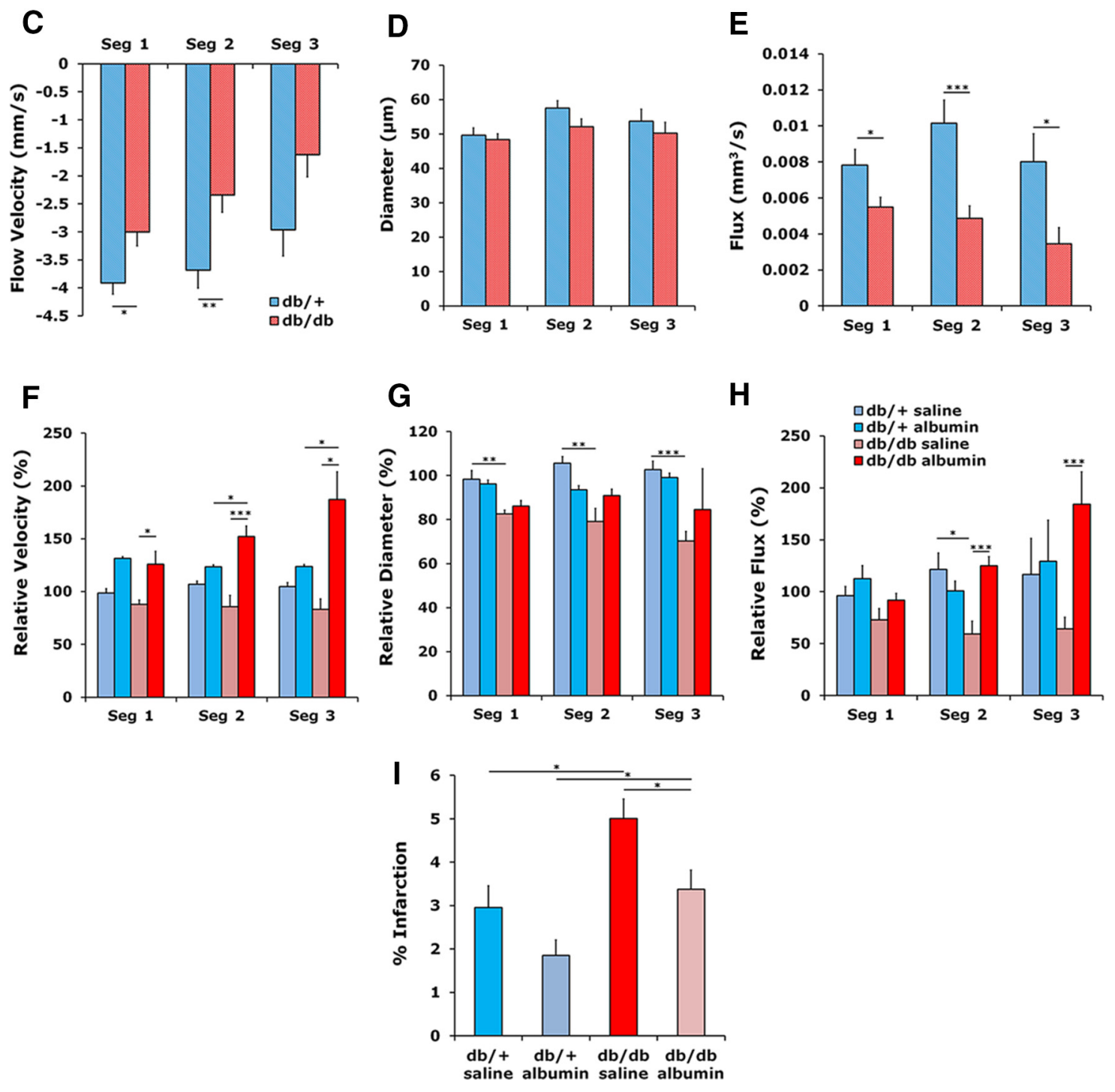

Figure 8. Continued.$$
\leftarrow
$$

Figure 8. Human albumin significantly enhances retrograde collateral flow to proximal MCA branches after ischemic reperfusion in $d b / d b$ mice. $A$, Timelines of stroke, imaging, and treatment. $\boldsymbol{B}$, Representative DOCT images at 30 and 90 min after reperfusion, respectively. Albumin or saline was infused at $60 \mathrm{~min}$ after reperfusion following the completion of the first DOCT scan. Dotted white lines indicate the divide between MCA and ACA territory. The anatomic orientation of the brain is indicated with arrows pointing to the medial $(M)$ and anterior $(A)$ directions. Compared with $d b /+$ mice, the impaired collateral flow status in $d b / d b$ mice persisted during reperfusion $(\boldsymbol{C}, \boldsymbol{E})$, whereas the diameter of MCA segments remained unchanged (D). Following saline administration, there was a significant reduction in the vessel diameter of all segments (G) compared with $d b /+$ mice. The relative increases in velocity in all segments were evident in $d b / d b$ mice comparing albumin- and saline-treated groups $(\boldsymbol{F})$. In particular, the relative increase in velocity was significantly greater in $\mathrm{Seg} 2$ and $\mathrm{Seg} 3$ in $\mathrm{db} / \mathrm{db}$ mice compared with $\mathrm{db} /+$ mice (white arrows). Similarly, the relative flux increase was observed in Seg2 and Seg3 in albumin-treated compared with saline-treated $d b / d b$ mice $(\boldsymbol{H})$. There was also a reduction in the relative flux following saline treatment in Seg 2 in the $d b / d b$ compared with $d b /+$ groups $(\boldsymbol{H})$. There was a significant reduction of infarct volume at $7 \mathrm{~d}$ after stroke following albumin compared with saline treatment in the $d b / d b$ mice ( $\boldsymbol{l}$. Although albumin significantly improved the disparity in lesion size between $d b /+$ and $d b / d b$ mice compared with that with saline treatment, $d b / d b$ mice in general still have a larger stroke size (two-way ANOVA: diabetic effect, $\left.F_{(1,18)}=15.7, p<0.001\right) .{ }^{*} p<0.05 .{ }^{* *} p<0.01 .{ }^{* * *} p<0.005$. ${ }^{* * *} p<0.001$. Scale bar, $1 \mathrm{~mm} . \mathrm{N}=5-8 /$ group.
}

collaterals in GK rats are consistent with the restoration of cerebral perfusion at $24 \mathrm{~h}$ after permanent MCAO, as well as reduced infarct size and Bederson score, despite the fact that GK rats have increased edema, vascular permeability, MMP2, and MMP9 levels compared with control. Interestingly, the increased collaterals were found in 10-week-old but not in younger 5-week-old GK rats before the onset of diabetes, suggesting that the increase might be related to hyperglycemia or other changes associated with diabetes. The potential factors contributing to the discrepancy in collaterals and stroke outcome between GK rats and $d b / d b$ mice are unknown, except that they are distinct models for T2DM. It would be of interest to learn whether the GK rats maintain the phenotype of increased collaterals at an older age as aging is associated with rarefaction of leptomeningeal anastomoses (Faber et al., 2011; Hecht et al., 2012).

The pathophysiological interaction between hyperglycemia and ischemic stroke is complex. Hyperglycemia not only exacerbates infarct growth as a consequence of lactic acidosis-related reduction of penumbra survival but also induces higher intracranial bleeding risk after thrombolytic treatment (Parsons et al., 2002; Wahlgren et al., 2008), although the association between hyper- 
glycemia and poor outcome after stroke is mainly relevant to patients with large-vessel infarction, not to those with lacuna stroke (Bruno et al., 1999; Uyttenboogaart et al., 2007), suggesting that hyperglycemia per se may not be the major cause of poor stroke outcome in T2DM patients. The effect of hyperglycemia on ischemic damage also remains controversial in experimental studies in which hyperglycemia had a protective, detrimental or no effect on ischemic injury in models of cerebral ischemia (Martini and Kent, 2007; MacDougall and Muir, 2011). It is not entirely clear whether the discrepancy could be attributed solely to differences in the level or model of hyperglycemia, animal species, or models of ischemia. Similarly, the findings in how hyperglycemia affects the regulation of cerebral blood flow after ischemia are also mixed (Martini and Kent, 2007; MacDougall and Muir, 2011; Tennant and Brown, 2013). In our study, we did not detect collateral flow impairment either at baseline or during MCAO when $d b /+$ mice were rendered temporarily hyperglycemic, indicating that hyperglycemia alone is not sufficient in causing collateral flow impairment. This suggests that other chronic vascular pathological mechanisms may underlie the observed impairment in collateral status in the diabetic animals with stroke.

Human albumin has emerged as a potent neuroprotective agent in experimental stroke due to its multiple salutary actions, including its beneficial hemodynamic and flow-enhancing effects (Keaney et al., 1993; Belayev et al., 2002; Nimmagadda et al., 2008). In the present study, albumin treatment significantly improved relative flow velocity and flux at the proximal MCA segment compared with saline treatment in the $d b / d b$ mice after ischemic reperfusion, whereas the benefits at the distal MCA segment were not apparent, possibly because of its proximity to ACA and a greater chance of receiving spontaneous restoration of collateral flow. In contrast to $d b / d b$ mice, albumin treatment showed less benefit in improving collateral flow and in reducing infarct size in the $d b /+$ mice. This is in line with the findings of a recent study that albumin had no flow-enhancing effect at distal MCAs in wild-type CD-1 mice who had relatively robust brain collateralization, compared with the more frank augmentation of collateral circulation in the poorly collateralized BALB/C strain (Defazio et al., 2012). Based on the above results and our data, albumin may be less effective to augment collateral flow in nonpathological and well-collateralized animals that already have a robust collateral compensation. Thus, albumin may have a more favorable effect on collateral augmentation in those with functionally or anatomically impaired collateral vessels. Furthermore, several mechanisms have been proposed to underlie albuminmediated intravascular effects, including intravascular volume expansion, hemodilution (Belayev et al., 1998), decreased red blood cell sedimentation under low-flow conditions (Defazio et al., 2012), and reduced platelet aggregation (Gresele et al., 1984; Nimmagadda et al., 2008). The latter studies may support our data showing that albumin improved the flux more efficiently in $d b / d b$ mice, albeit predisposed to increased platelet accumulation and thrombi formation (Obrenovitch and Hallenbeck, 1985; Braaten et al., 1993; Granger et al., 2010). The ability of albumin in inhibiting platelet aggregation by sequestering arachidonic acid released into extracellular space (Porcellati et al., 1995) cannot be substituted by the simple dilution effect of saline.

In conclusion, we found that T2DM mice exhibited impaired leptomeningeal collateral flow recruitment during stroke that was not attributable to acute hyperglycemia. Albumin treatment reduced collateral flow impairment and infarction volume by augmenting collateral flow, particularly at proximal MCAs. The failure of collaterization in T2DM mice via both primary and secondary collateral pathways during chronic hypoperfusion may contribute to hemodynamic compromise that increases the risk for ischemic stroke.

\section{References}

Alessi MC, Juhan-Vague I (2006) PAI-1 and the metabolic syndrome: links, causes, and consequences. Arterioscler Thromb Vasc Biol 26:2200-2207. CrossRef Medline

Armitage GA, Todd KG, Shuaib A, Winship IR (2010) Laser speckle contrast imaging of collateral blood flow during acute ischemic stroke. J Cereb Blood Flow Metab 30:1432-1436. CrossRef Medline

Belayev L, Zhao W, Pattany PM, Weaver RG, Huh PW, Lin B, Busto R, Ginsberg MD (1998) Diffusion-weighted magnetic resonance imaging confirms marked neuroprotective efficacy of albumin therapy in focal cerebral ischemia. Stroke 29:2587-2599. CrossRef Medline

Belayev L, Liu Y, Zhao W, Busto R, Ginsberg MD (2001) Human albumin therapy of acute ischemic stroke: marked neuroprotective efficacy at moderate doses and with a broad therapeutic window. Stroke 32:553-560. CrossRef Medline

Belayev L, Pinard E, Nallet H, Seylaz J, Liu Y, Riyamongkol P, Zhao W, Busto R, Ginsberg MD (2002) Albumin therapy of transient focal cerebral ischemia: in vivo analysis of dynamic microvascular responses. Stroke 33:1077-1084. CrossRef Medline

Braaten JV, Handt S, Jerome WG, Kirkpatrick J, Lewis JC, Hantgan RR (1993) Regulation of fibrinolysis by platelet-released plasminogen activator inhibitor 1: light scattering and ultrastructural examination of lysis of a model platelet-fibrin thrombus. Blood 81:1290-1299. Medline

Bruno A, Biller J, Adams HP Jr, Clarke WR, Woolson RF, Williams LS, Hansen MD (1999) Acute blood glucose level and outcome from ischemic stroke: Trial of ORG 10172 in Acute Stroke Treatment (TOAST) Investigators. Neurology 52:280-284. CrossRef Medline

Caplan LR, Hennerici M (1998) Impaired clearance of emboli (washout) is an important link between hypoperfusion, embolism, and ischemic stroke. Arch Neurol 55:1475-1482. CrossRef Medline

Chen J, Cui X, Zacharek A, Cui Y, Roberts C, Chopp M (2011) White matter damage and the effect of matrix metalloproteinases in type 2 diabetic mice after stroke. Stroke 42:445-452. CrossRef Medline

Defazio RA, Zhao W, Deng X, Obenaus A, Ginsberg MD (2012) Albumin therapy enhances collateral perfusion after laser-induced middle cerebral artery branch occlusion: a laser speckle contrast flow study. J Cereb Blood Flow Metab 32:2012-2022. CrossRef Medline

Dobrin PB, Schwarcz TH, Baker WH (1988) Mechanisms of arterial and aneurysmal tortuosity. Surgery 104:568-571. Medline

Emerging Risk Factors Collaboration, Sarwar N, Gao P, Seshasai SR, Gobin R, Kaptoge S, Di Angelantonio E, Ingelsson E, Lawlor DA, Selvin E, Stampfer M, Stehouwer CD, Lewington S, Pennells L, Thompson A, Sattar N, White IR, Ray KK, Danesh J (2010) Diabetes mellitus, fasting blood glucose concentration, and risk of vascular disease: a collaborative metaanalysis of 102 prospective studies. Lancet 375:2215-2222. CrossRef Medline

Faber JE, Zhang H, Lassance-Soares RM, Prabhakar P, Najafi AH, Burnett MS, Epstein SE (2011) Aging causes collateral rarefaction and increased severity of ischemic injury in multiple tissues. Arterioscler Thromb Vasc Biol 31:1748-1756. CrossRef Medline

Faber JE, Chilian WM, Deindl E, van Royen N, Simons M (2014) A brief etymology of the collateral circulation. Arterioscler Thromb Vasc Biol 34:1854-1859. CrossRef Medline

Fuentes B, Castillo J, San José B, Leira R, Serena J, Vivancos J, Dávalos A, Nuñez AG, Egido J, Díez-Tejedor E, Díez-Tejedor E (2009) The prognostic value of capillary glucose levels in acute stroke: the GLycemia in Acute Stroke (GLIAS) study. Stroke 40:562-568. CrossRef Medline

Goto Y, Kakizaki M, Masaki N (1976) Production of spontaneous diabetic rats by repetition of selective breeding. Tohoku J Exp Med 119:85-90. CrossRef Medline

Granger DN, Rodrigues SF, Yildirim A, Senchenkova EY (2010) Microvascular responses to cardiovascular risk factors. Microcirculation 17:192205. CrossRef Medline

Grant PJ (2007) Diabetes mellitus as a prothrombotic condition. J Intern Med 262:157-172. CrossRef Medline

Gresele P, Deckmyn H, Huybrechts E, Vermylen J (1984) Serum albumin enhances the impairment of platelet aggregation with thromboxane syn- 
thase inhibition by increasing the formation of prostaglandin D2. Biochem Pharmacol 33:2083-2088. CrossRef Medline

Hecht N, He J, Kremenetskaia I, Nieminen M, Vajkoczy P, Woitzik J (2012) Cerebral hemodynamic reserve and vascular remodeling in C57BL/6 mice are influenced by age. Stroke 43:3052-3062. CrossRef Medline

Hill MD, Martin RH, Palesch YY, Tamariz D, Waldman BD, Ryckborst KJ, Moy CS, Barsan WG, Ginsberg MD (2011) The Albumin in Acute Stroke Part 1 Trial: an exploratory efficacy analysis. Stroke 42:1621-1625. CrossRef Medline

Hoi Y, Gao L, Tremmel M, Paluch RA, Siddiqui AH, Meng H, Mocco J (2008) In vivo assessment of rapid cerebrovascular morphological adaptation following acute blood flow increase. J Neurosurg 109:1141-1147. CrossRef Medline

Keaney JF Jr, Simon DI, Stamler JS, Jaraki O, Scharfstein J, Vita JA, Loscalzo J (1993) NO forms an adduct with serum albumin that has endothelium-derived relaxing factor-like properties. J Clin Invest 91:1582-1589. CrossRef Medline

Kumari R, Willing LB, Patel SD, Baskerville KA, Simpson IA (2011) Increased cerebral matrix metalloprotease- 9 activity is associated with compromised recovery in the diabetic $d b / d b$ mouse following a stroke. J Neurochem 119:1029-1040. CrossRef Medline

Li Q, Atochin D, Kashiwagi S, Earle J, Wang A, Mandeville E, Hayakawa K, d'Uscio LV, Lo EH, Katusic Z, Sessa W, Huang PL (2013) Deficient eNOS phosphorylation is a mechanism for diabetic vascular dysfunction contributing to increased stroke size. Stroke 44:3183-3188. CrossRef Medline

Li W, Prakash R, Kelly-Cobbs AI, Ogbi S, Kozak A, El-Remessy AB, Schreihofer DA, Fagan SC, Ergul A (2010) Adaptive cerebral neovascularization in a model of type 2 diabetes: relevance to focal cerebral ischemia. Diabetes 59:228-235. CrossRef Medline

Li Y, Song Y, Zhao L, Gaidosh G, Laties AM, Wen R (2008) Direct labeling and visualization of blood vessels with lipophilic carbocyanine dye DiI. Nat Protoc 3:1703-1708. CrossRef Medline

Liebeskind DS (2003) Collateral circulation. Stroke 34:2279-2284. CrossRef Medline

Liebeskind DS (2013) Trials of endovascular therapies or collaterals? Int J Stroke 8:258-259. CrossRef Medline

Liu J, Wang Y, Akamatsu Y, Lee CC, Stetler RA, Lawton MT, Yang GY (2013) Vascular remodeling after ischemic stroke: mechanisms and therapeutic potentials. Prog Neurobiol 115:138-156. CrossRef Medline

MacDougall NJ, Muir KW (2011) Hyperglycaemia and infarct size in animal models of middle cerebral artery occlusion: systematic review and meta-analysis. J Cereb Blood Flow Metab 31:807-818. CrossRef Medline

Majid A, He YY, Gidday JM, Kaplan SS, Gonzales ER, Park TS, Fenstermacher JD, Wei L, Choi DW, Hsu CY (2000) Differences in vulnerability to permanent focal cerebral ischemia among 3 common mouse strains. Stroke 31:2707-2714. CrossRef Medline

Martini SR, Kent TA (2007) Hyperglycemia in acute ischemic stroke: a vascular perspective. J Cereb Blood Flow Metab 27:435-451. CrossRef Medline

Megherbi SE, Milan C, Minier D, Couvreur G, Osseby GV, Tilling K, Di Carlo A, Inzitari D, Wolfe CD, Moreau T, Giroud M (2003) Association between diabetes and stroke subtype on survival and functional outcome 3 months after stroke: data from the European BIOMED Stroke Project. Stroke 34:688-694. CrossRef Medline

Menon BK, Smith EE, Coutts SB, Welsh DG, Faber JE, Goyal M, Hill MD, Demchuk AM, Damani Z, Cho KH, Chang HW, Hong JH, Sohn SI (2013) Leptomeningeal collaterals are associated with modifiable metabolic risk factors. Ann Neurol 74:241-248. Medline

Nimmagadda A, Park HP, Prado R, Ginsberg MD (2008) Albumin therapy improves local vascular dynamics in a rat model of primary microvascular thrombosis: a two-photon laser-scanning microscopy study. Stroke 39: 198-204. CrossRef Medline

Obrenovitch TP, Hallenbeck JM (1985) Platelet accumulation in regions of low blood flow during the postischemic period. Stroke 16:224-234. CrossRef Medline

Parsons MW, Barber PA, Desmond PM, Baird TA, Darby DG, Byrnes G, Tress
BM, Davis SM (2002) Acute hyperglycemia adversely affects stroke outcome: a magnetic resonance imaging and spectroscopy study. Ann Neurol 52:20-28. CrossRef Medline

Porcellati S, Gresele P, Stasi M, Buratta S, Horrocks LA, De Franceschi S, Nenci GG, Goracci G (1995) Albumin prevents TxB, formation from thrombin-stimulated human platelets by sequestering the liberated arachidonic acid in the extracellular space. Platelets 6:381-387. CrossRef Medline

Raber J, Fan Y, Matsumori Y, Liu Z, Weinstein PR, Fike JR, Liu J (2004) Irradiation attenuates neurogenesis and exacerbates ischemia-induced deficits. Ann Neurol 55:381-389. CrossRef Medline

Sangle GV, Zhao R, Mizuno TM, Shen GX (2010) Involvement of RAGE, NADPH oxidase, and Ras/Raf-1 pathway in glycated LDL-induced expression of heat shock factor- 1 and plasminogen activator inhibitor-1 in vascular endothelial cells. Endocrinology 151:4455-4466. CrossRef Medline

Santisakultarm TP, Schaffer CB (2011) Optically quantified cerebral blood flow. J Cereb Blood Flow Metab 31:1337-1338. CrossRef Medline

Schaffer CB, Friedman B, Nishimura N, Schroeder LF, Tsai PS, Ebner FF, Lyden PD, Kleinfeld D (2006) Two-photon imaging of cortical surface microvessels reveals a robust redistribution in blood flow after vascular occlusion. PLoS Biol 4:e22. CrossRef Medline

Shih AY, Friedman B, Drew PJ, Tsai PS, Lyden PD, Kleinfeld D (2009) Active dilation of penetrating arterioles restores red blood cell flux to penumbral neocortex after focal stroke. J Cereb Blood Flow Metab 29:738-751. CrossRef Medline

Shuaib A, Butcher K, Mohammad AA, Saqqur M, Liebeskind DS (2011) Collateral blood vessels in acute ischaemic stroke: a potential therapeutic target. Lancet Neurol 10:909-921. CrossRef Medline

Srinivasan VJ, Atochin DN, Radhakrishnan H, Jiang JY, Ruvinskaya S, Wu W, Barry S, Cable AE, Ayata C, Huang PL, Boas DA (2011) Optical coherence tomography for the quantitative study of cerebrovascular physiology. J Cereb Blood Flow Metab 31:1339-1345. CrossRef Medline

Sun C, Sun H, Wu S, Lee CC, Akamatsu Y, Wang RK, Kernie SG, Liu J (2013) Conditional ablation of neuroprogenitor cells in adult mice impedes recovery of poststroke cognitive function and reduces synaptic connectivity in the perforant pathway. J Neurosci 33:17314-17325. CrossRef Medline

Tennant KA, Brown CE (2013) Diabetes augments in vivo microvascular blood flow dynamics after stroke. J Neurosci 33:19194-19204. CrossRef Medline

Thompson SG, Kienast J, Pyke SD, Haverkate F, van de Loo JC (1995) Hemostatic factors and the risk of myocardial infarction or sudden death in patients with angina pectoris: European Concerted Action on Thrombosis and Disabilities Angina Pectoris Study Group. N Engl J Med 332:635641. CrossRef Medline

Trost S, Pratley R, Sobel B (2006) Impaired fibrinolysis and risk for cardiovascular disease in the metabolic syndrome and type 2 diabetes. Curr Diab Rep 6:47-54. CrossRef Medline

Uyttenboogaart M, Koch MW, Stewart RE, Vroomen PC, Luijckx GJ, De Keyser J (2007) Moderate hyperglycaemia is associated with favourable outcome in acute lacunar stroke. Brain 130:1626-1630. CrossRef Medline

Wahlgren N, Ahmed N, Dávalos A, Hacke W, Millán M, Muir K, Roine RO, Toni D, Lees KR (2008) Thrombolysis with alteplase 3-4.5 h after acute ischaemic stroke (SITS-ISTR): an observational study. Lancet 372:13031309. CrossRef Medline

Wang RK, An L (2009) Doppler optical micro-angiography for volumetric imaging of vascular perfusion in vivo. Opt Express 17:8926-8940. CrossRef Medline

Won SJ, Tang XN, Suh SW, Yenari MA, Swanson RA (2011) Hyperglycemia promotes tissue plasminogen activator-induced hemorrhage by increasing superoxide production. Ann Neurol 70:583-590. CrossRef Medline

Zhang L, Schallert T, Zhang ZG, Jiang Q, Arniego P, Li Q, Lu M, Chopp M (2002) A test for detecting long-term sensorimotor dysfunction in the mouse after focal cerebral ischemia. J Neurosci Methods 117:207-214. CrossRef Medline 